
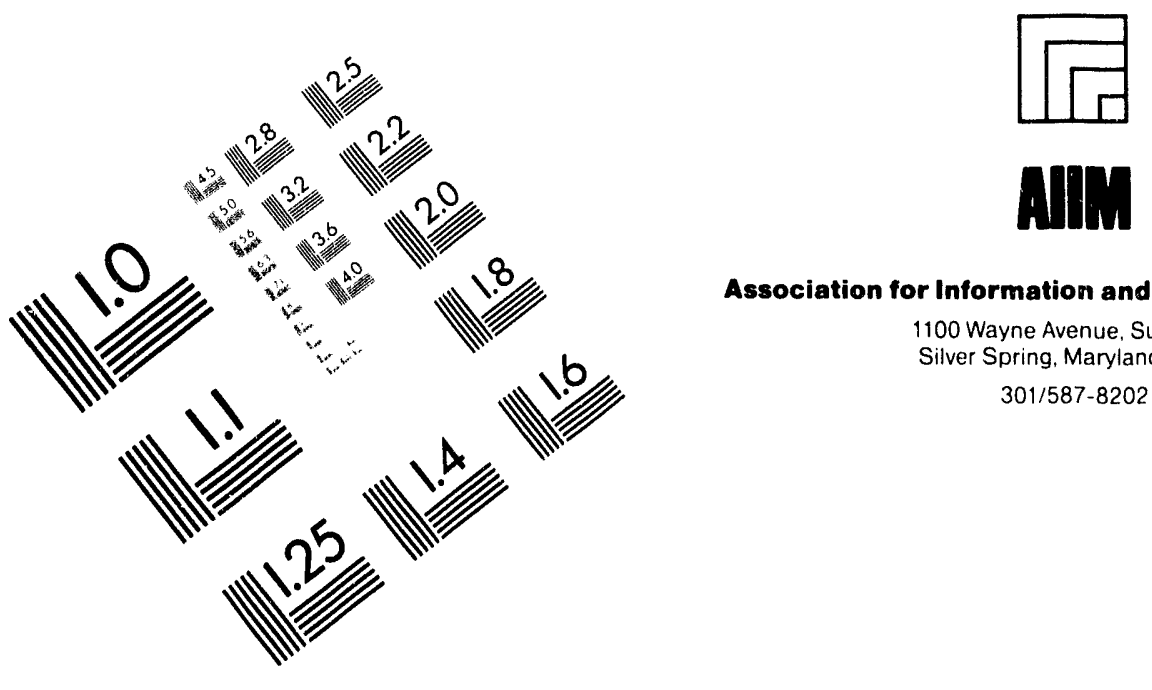

Association for Information and Image Management

1100 Wayne Avenue. Suite 1100

Silver Spring, Maryland 20910

301/587-8202

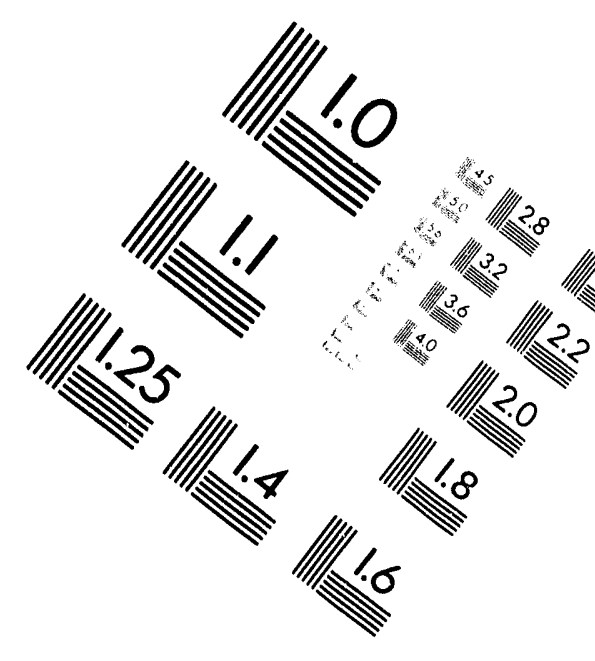

Centimeter

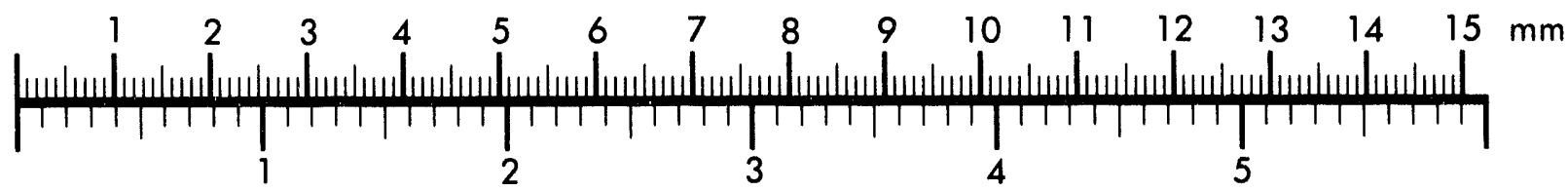

Inches
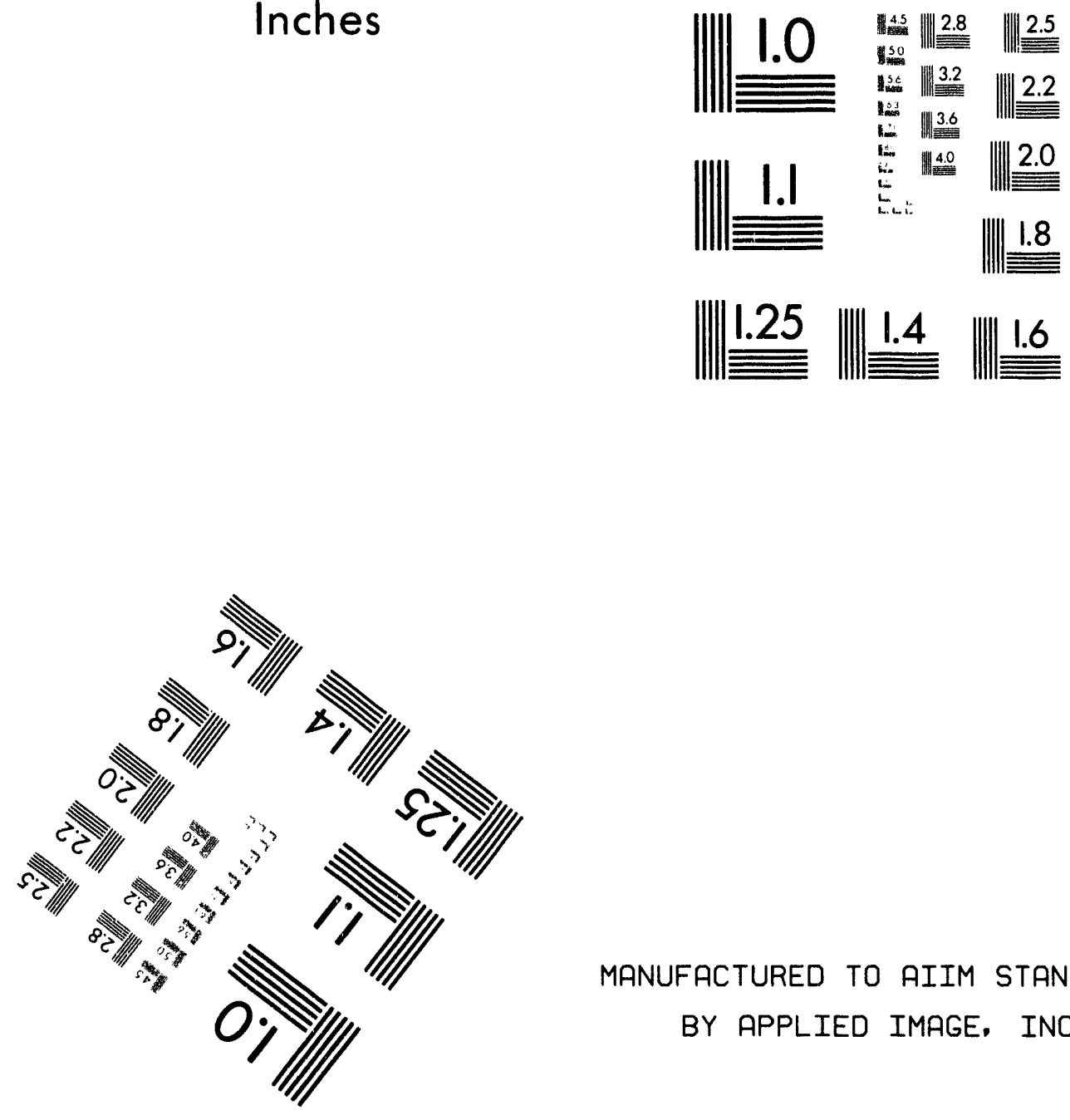

MANUFACTURED TO AIIM STANDARDS

BY APPLIED IMAGE. INC.

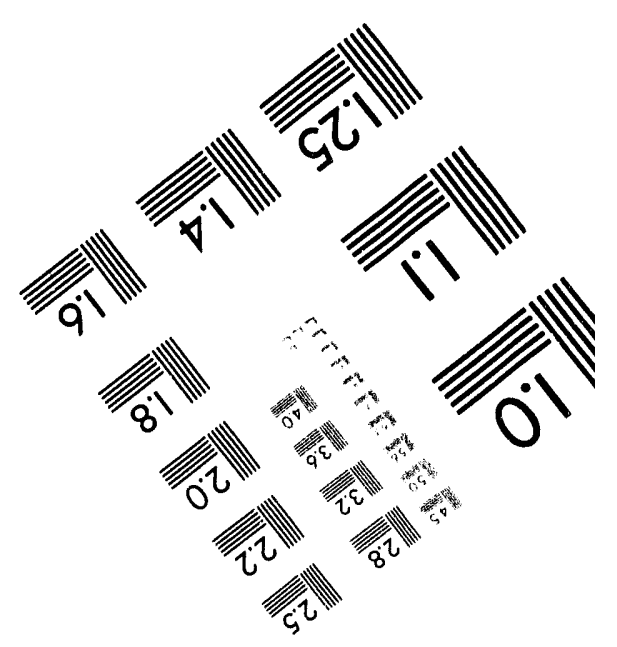



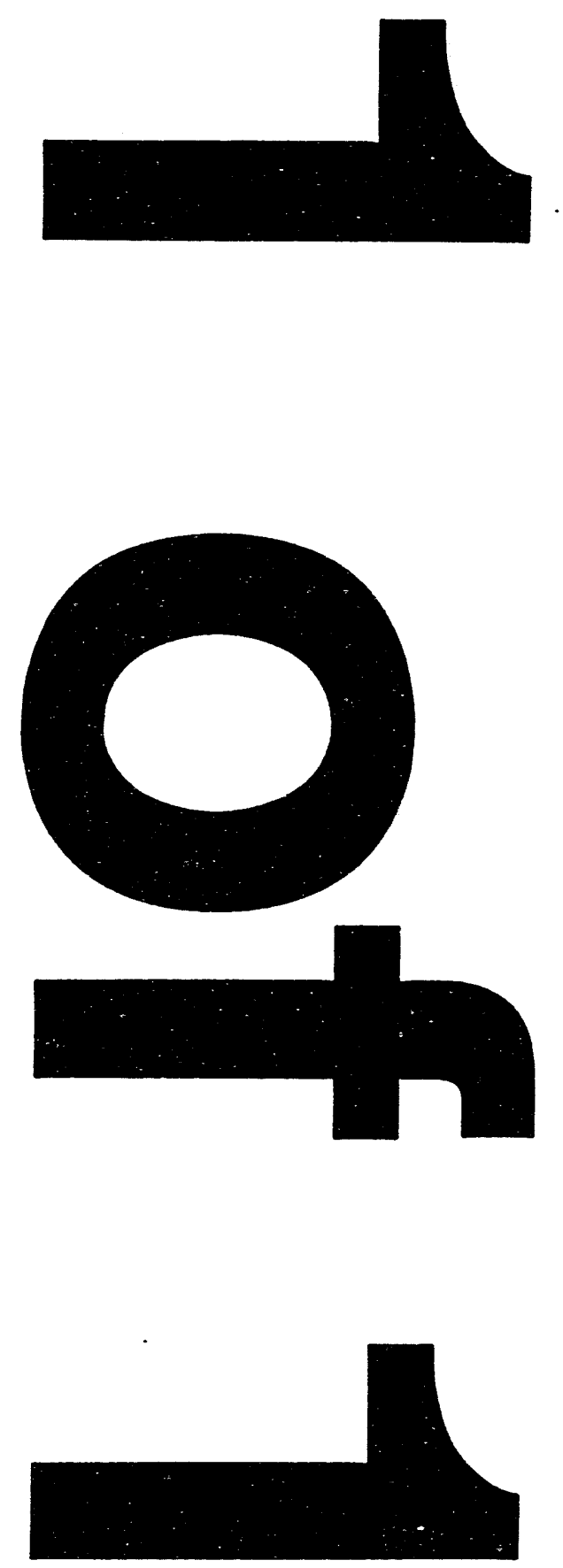


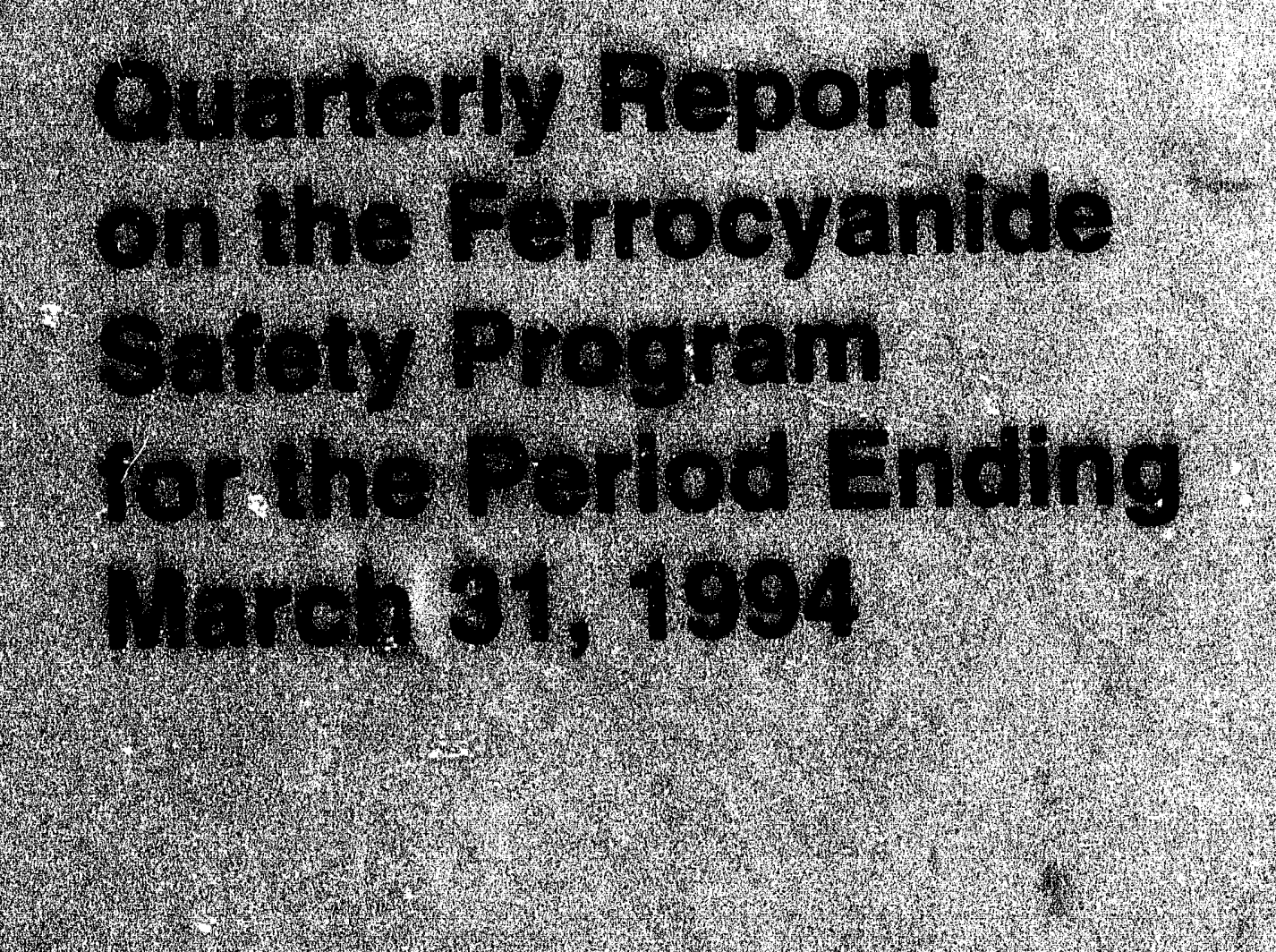

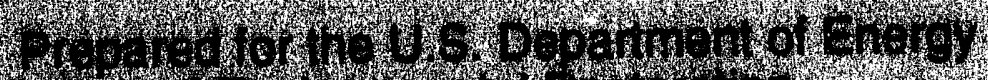

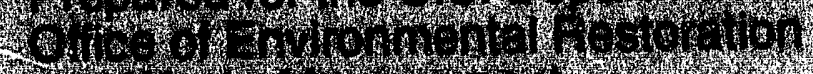

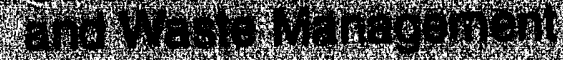

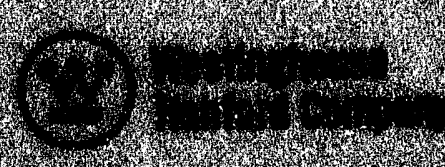

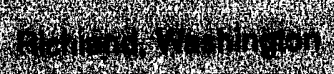

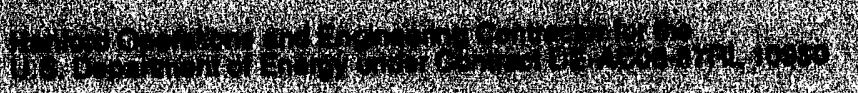

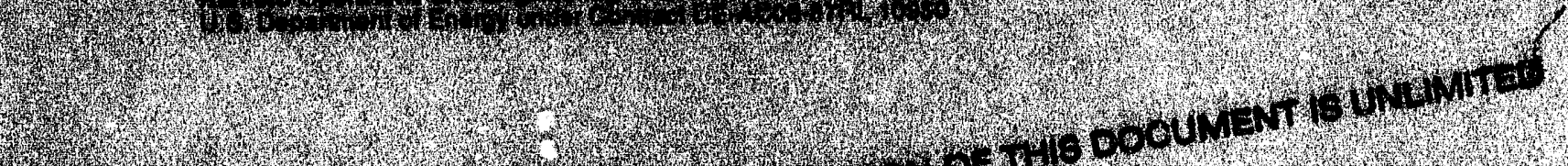

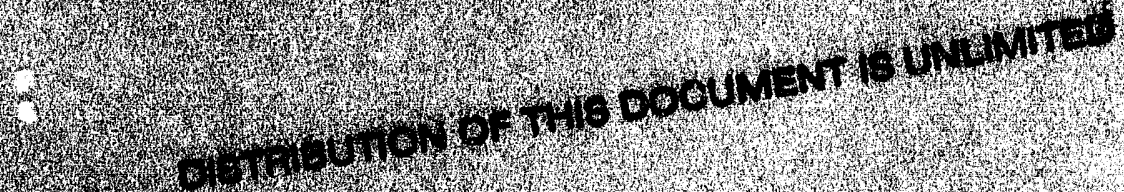
4.

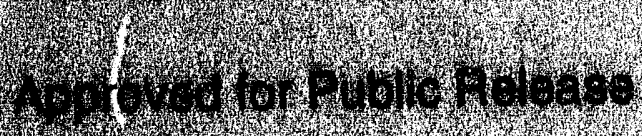




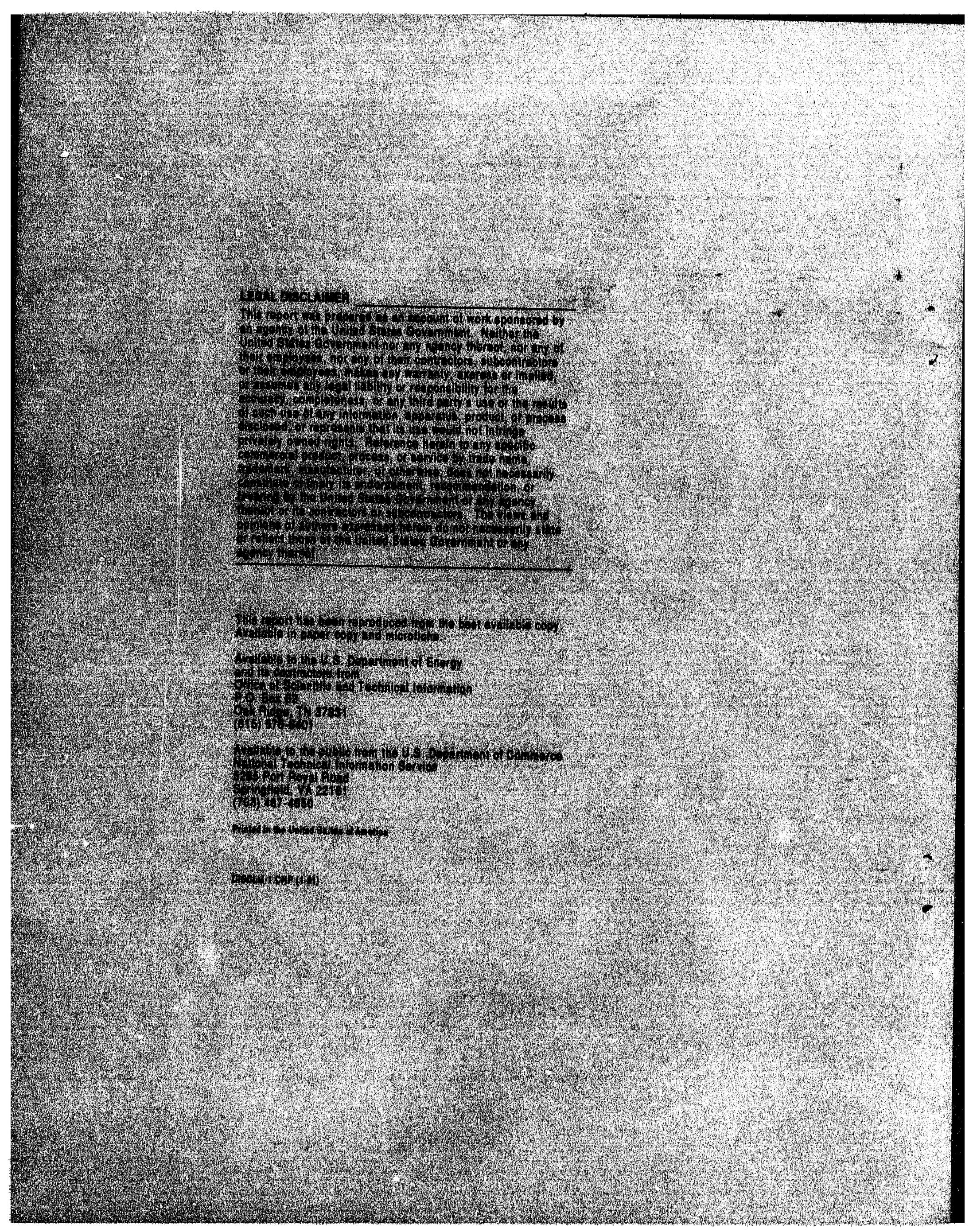




\title{
Quarterly Report on the Ferrocyanide Safety Program for the Period Ending March 31, 1994
}

\author{
J. E. Meacham \\ R. J. Cash \\ G. T. Dukelow
}

Date Published

April 1994

Prepared for the U.S. Department of Energy Office of Environmental Restoration and Waste Management

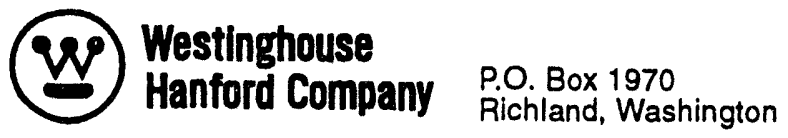

Hanford Operations and Engineering Contractor for the

U.S. Department of Energy under Contract DE-AC06-87RL 10930

DISTRIBUTION OF THIS DOCUMENT IS UNLIMITED 


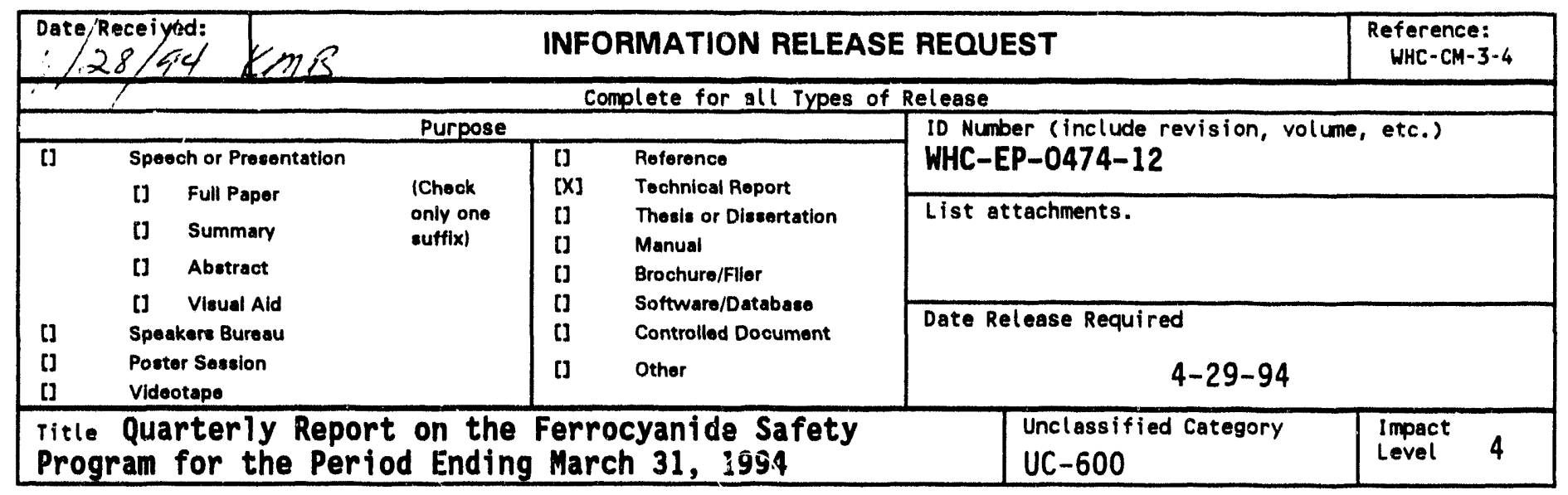

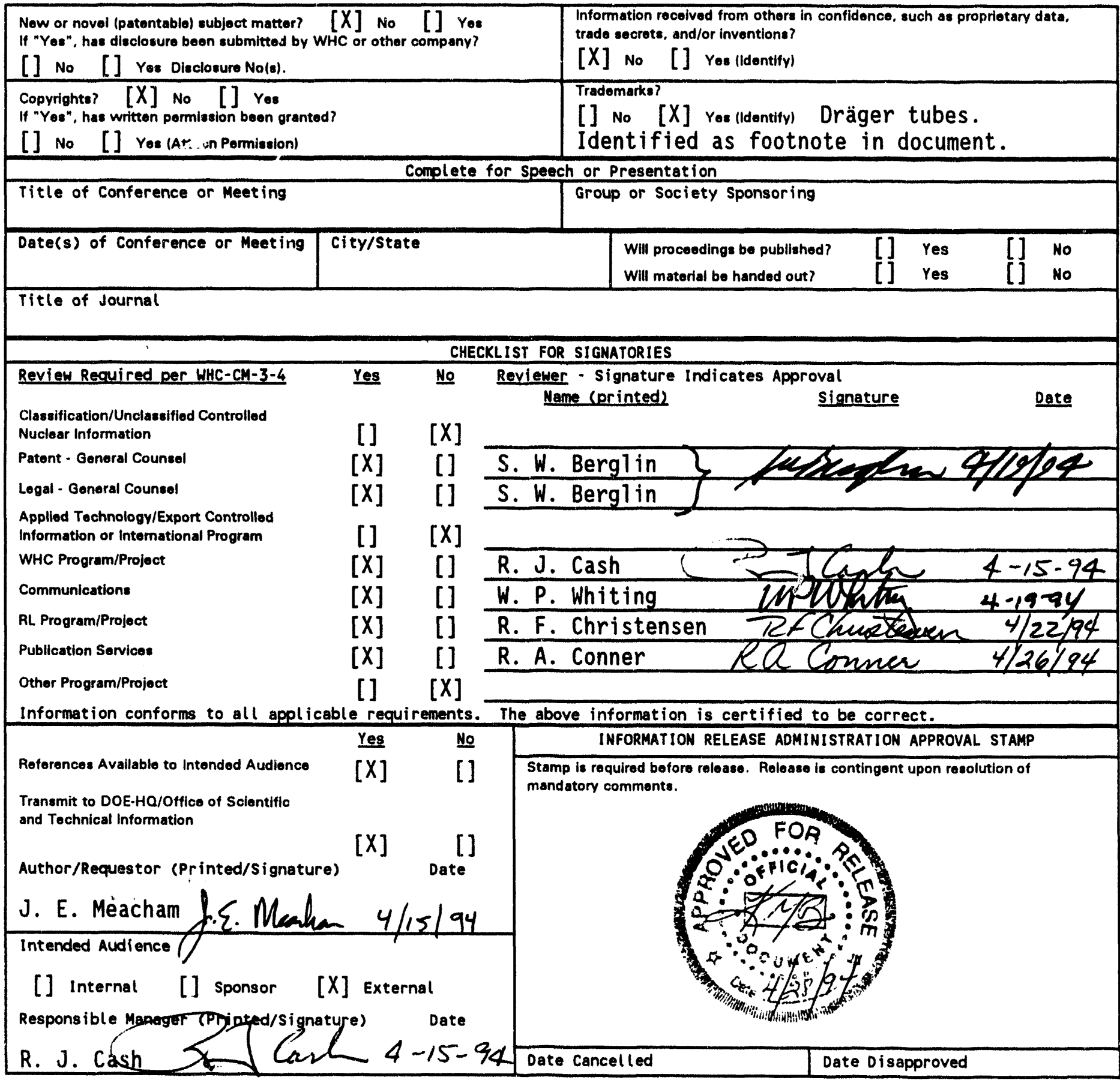




\title{
QUARTERLY REPORT ON THE FERROCYANIDE SAFETY PROGRAM FOR THE PERIOD ENDING MARCH 31, 1994
}

\author{
J. E. Meacham \\ R. J. Cash \\ G. T. Dukelow
}

\section{EXECUTIVE SUMMARY}

This is the twelfth quarterly report on the progress of activities addressing the Ferrocyanide Safety Issue associated with Hanford Site high-level radioactive waste tanks. In response to the Defense Nuclear Facilities Safety Board Recommendation 90-7 (FR 1990), an implementation plan was issued in March 1991 (Cash 1991). It described activities planned and undenway addressing each of the six parts of Recommendation 90-7. The implementation plan was updated and released in March 1994 as the Ferrocyanide Safety Program plan (Borsheim et al. 1994). The program plan still addresses the six parts of Recommendation 90-7, but also includes all work in the Ferrocyanide Safety Program. This quarterly report is reported against the new program plan.

An important milestone was completed this quarter, closure of the Ferrocyanide Unreviewed Safety Question. The Ferrocyanide Unreviewed Safety Question was closed on March 1, 1994 by the U.S. Department of Energy's Assistant Secretary for Environmental Restoration and Waste Management (Sheridan 1994). Closure of the Unreviewed Safery Question completes accelerated Safety Initiative milestone $2 s$ and Tri-Party Agreement milestone $M-40-14$. 
U.S. Department of Energy comments were incorporated into the ferrocyanide safety criteria document and the report was publicly released this quarter (Postma et al. 1994). An engineering change notice, integrating the information contained in the ferrocyanide safety criteria document, was written for the Hanford Site Tank Farm Facilities Interim Safety Basis (Wagoner 1993). An Unreviewed Safety Question screening on the ferrocyanide tanks was also completed this quarter. These efforts provided the basis for the U.S. Department of Energy's concurrence to close of the Ferrocyanide Unreviewed Safety Question.

Review comments on the ferrocyanide program plan were incorporated and the program plan was released this quarter (Borsheim et al. 1994). The program plan describes current and anticipated future work in the Ferrocyanide Safety Program leading to resolution of the Ferrocyanide Safety Issue. Schedules showing program activities leading to the final safety issue resolution are presented in the program plan. Work in the Ferrocyanide Safety Program is reported against the new program plan on a quarterly basis.

The generic Environmental Assessment, covering tank farm operations (including installation of instrument trees into assumed leaker ferrocyanide tanks and rotary core sampling), was approved this quarter, and a Finding of No Significant Impact was issued by the U.S. Department of Energy. Approval of the generic Environmental Assessment streamlines the approval process. The generic Environmental Assessment provides adequate National Environmental Policy Act coverage for planned Ferrocyanide and other Waste Tank Safety Program activities. 
$A$ draft document was prepared this quarter describing criteria for upgraded temperature monitoring capabilities in ferrocyanide tanks. This draft addresses a recently established Tri-Party Agreement milestone (M-40-02A) due in September 1994. The document concludes that one instrument tree is sufficient to monitor temperature in the ferrocyanide tanks, given the current knowledge of the ferrocyanide hazard. The draft document is currently undergoing review by Westinghouse Hanford Company, the U.S. Department of Energy, and the Washington State Department of Ecology.

New information on the thermal conductivity of soils surrounding the waste storage tanks was incorporated into the heat load model. Thermal conductivity data from soil analyses revealed that conductivity values are greater than those used previously. Tank heat load estimates using the new conductivity data are consistent with other independent estimates Borsheim and Simpson 1991; Crowe et al. 1993).

$A$ draft report evaluating potential sources of flammable gases, including potential cyclic venting, was also prepared this quarter. The report concludes that continuous vapor monitoring in ferrocyanide tanks is not warranted. The draft study is undergoing technical review by Wcstinghouse Hanford Company and the U.S. Department of Energy. The report will be released next quarter.

The results of a preliminary study were released this quarter on remote Fourier Transform infrared spectroscopy techniques presently being considered for in situ and/or hot cell ferrocyanide applications (Rebagay et al. 1994). In general, the spectra obtained using the 
remote systems resembled those collected from the same waste using conventional Fourier Transform infrared sampling accessories.

Two aging experiments were completed this quarter. In Farm ferrocyanide waste simulant was mixed with two molar sodium hydroxide and exposed to gamma irradiation for three weeks at 70 and $90^{\circ} \mathrm{C}$. Results show that the rate of ferrocyanide destruction is temperature dependent. At $90{ }^{\circ} \mathrm{C}$ approximately $60 \%$ of the cyanide groups were hydrolyzed, and at $70^{\circ} \mathrm{C}$, less than $5 \%$ of the cyanide groups were hydrolyzed during this time period.

Experiments designed to more accurately define the minimum fuel concentration required to support a ferrocyanide propagating reaction were conducted at Fauske and Associates, Inc. this quarter. Tests using dried ferrocyanide waste simulant mixtures showed that the minimum propagation concentration was between 13 and 14 wt \% las disodium nickel ferrocyanide]. A test conducted at 14 wt \% propagated at a very slow rate, while two tests conducted at 12 and $13 w t \%$ did not support propagation. A report on $T$ Plant calorimetry and propagation tests conducted earlier was also released this quarter (Fauske and Jeppson 1994). Experiments demonstrated that $T$ Plant simulant does not support a propagating reaction. 


\section{CONTENTS}

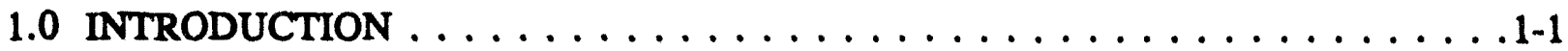

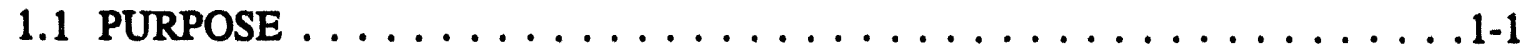

1.2 QUARTERLY HIGHLIGHTS $\ldots \ldots \ldots \ldots \ldots \ldots \ldots \ldots \ldots \ldots \ldots$

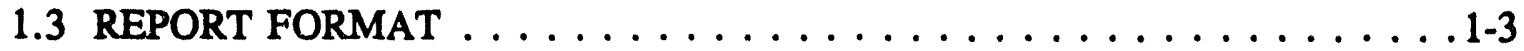

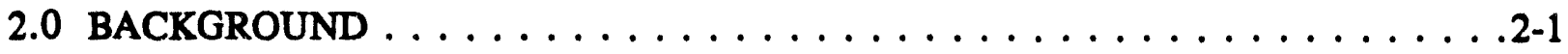

3.0 FERROCYANIDE SAFETY DOCUMENTATION $\ldots \ldots \ldots \ldots \ldots$ 3-1

4.0 DESCRIPTION OF ACTIVITIES . . . . . . . . . . . . . 4-1

4.1 ENHANCED TEMPERATURE MEASUREMENT $\ldots \ldots \ldots \ldots \ldots \ldots$ 4-1

4.1.1 Instrument Trees . . . . . . . . . . . . . . . 4-1

4.1.2 Upgrades to Existing Temperature Monitoring Instrumentation . . . 4-2

4.1.3 Hot Spot Thermal Modeling . . . . . . . . . . . . . 4-3

4.1.4 Infrared Scanning System . . . . . . . . . . . . . . . 4-4

4.2 CONTINUOUS TEMPERATURE MONITORING $\ldots \ldots \ldots \ldots \ldots \ldots$ 4-5

4.3 COVER GAS MODELING $\ldots \ldots \ldots \ldots \ldots \ldots \ldots \ldots \ldots$. . . . . . .

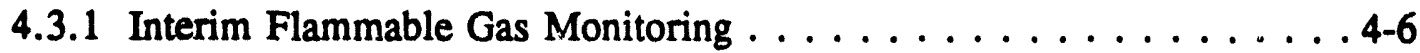

4.3.2 Continuous Gas Monitoring $\ldots \ldots \ldots \ldots \ldots \ldots \ldots$. . . . . . . . .

4.3.3 Tank Pressure Monitoring . . . . . . . . . . . . . . . . 4-9

4.4 FERROCYANIDE WASTE CHARACTERIZATION $\ldots \ldots \ldots \ldots \ldots$ 4-10

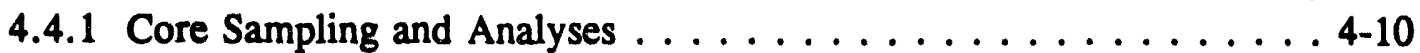

4.4.2 Estimation of Moisture Content . . . . . . . . . . 4-14

4.4.3 Preparation and Characterization of Ferrocyanide Waste Simulants . 4-20

4.5 CHEMICAL REACTION STUDIES . . . . . . . . . . . . . . 4-23

4.5.1 Chemical Reaction Studies at Pacific Northwest Laboratory . . . . . 4-23

4.5.2 Ferrocyanide Propagation Studies . . . . . . . . . . 4-29

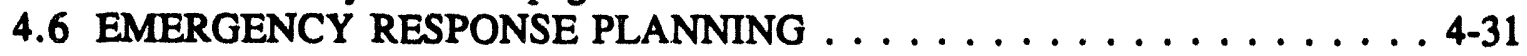

5.0 PROGRAM SCHEDULES AND MILESTONES $\ldots \ldots \ldots \ldots \ldots \ldots$. $\ldots \ldots$

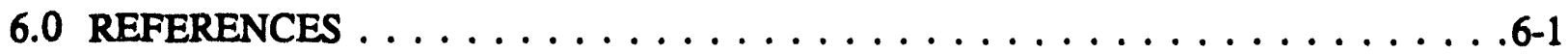

\section{APPENDIXES}

APPENDIX A FERROCYANIDE TANKS . . . . . . . . . . A-1

APPENDIX B METRIC CONVERSION CHART $\ldots \ldots \ldots \ldots \ldots \ldots$ B-1 


\section{LIST OF FIGURES}

4-1 Cross-Sectional View of the Geometry, Materials, and Calculated Neutron Interaction Densities Modeled to Represent Tank 241-BY-111. . . . . . . . . 4-17

4-2 Weight Percent of Free Water Remaining as a Function of Time. . . . . . . 4-21

4-3 Dis olution of Vendor Material in $4 M \mathrm{NaOH}$ in the Presence of $3 \times 10^{-3}$ and $3 \times 10^{-4} M$ Cs Ion . . . . . . . . . . . . . . 4-24

4-4 Ammonia Production During the Irradiation of In Farm 1 Simulant at

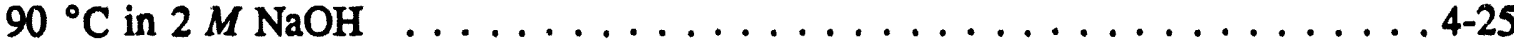

4-5 Comparison of Ammonia Production at 70 and $90{ }^{\circ} \mathrm{C}$ During Irradiation of In Farm 1 Simulant in $2 M \mathrm{NaOH} \ldots \ldots \ldots \ldots \ldots \ldots \ldots \ldots \ldots . \ldots \ldots$

4-6 Bifurcated Flow Field in Porous Waste Sludge $\ldots \ldots \ldots \ldots$. . . . . . . . 4-27

5-1 Ferrocyanide Waste Tank Safety Schedule. . . . . . . . . . . . 5-2

5-2 Ferrocyanide Waste Tank Safety Schedule (Out Year) $\ldots \ldots \ldots \ldots$. . . . .

\section{LIST OF TABLES}

4-1 Spacial Examination of Data Obtained from Tank 241-T-107. . . . . . . . 4-11

4-2 Effect of Adding $\mathrm{CsNO}_{3}$ to $20 \mathrm{mg} \mathrm{Ni}_{2} \mathrm{Fe}(\mathrm{CN})_{6}$ Suspensions in

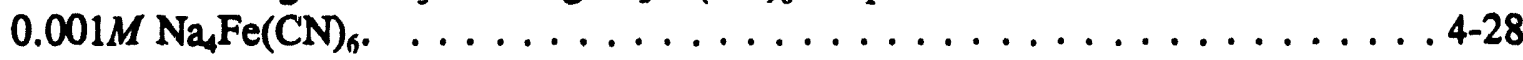

A-1 Summary of Contents and Status of Ferrocyanide Tanks $\ldots \ldots \ldots \ldots \ldots$ A-3

A-2 Ferrocyanide Tank Vapor Sampling Summary $\ldots \ldots \ldots \ldots \ldots$ A-5

B-1 Metric Conversion Chart $\ldots \ldots \ldots \ldots \ldots \ldots \ldots \ldots \ldots$ B-3 


\section{LIST OF TERMS}

$\begin{array}{ll}\text { CASS } & \text { Computer Automated Surveillance System } \\ \text { CPAC } & \text { Center for Process Analytical Chemistry } \\ \text { DNFSB } & \text { Defense Nuclear Facilities Safety Board } \\ \text { DOE } & \text { U.S. Department of Energy } \\ \text { DQO } & \text { Data Quality Objectives } \\ \text { EIS } & \text { Environmental Impact Statement } \\ \text { EA } & \text { Environmental Assessment } \\ \text { FAI } & \text { Fauske and Associates, Inc. } \\ \text { FTIR } & \text { Fourier Transform Infrared } \\ \text { FTIR-PAS } & \text { Fourier Transform Infrared-Photoacoustic Spectroscopy } \\ \text { FY } & \text { Fiscal Year } \\ \text { GAO } & \text { General Accounting Office } \\ \text { IC } & \text { Ion Chromatography } \\ \text { IR } & \text { Infrared } \\ \text { ISB } & \text { Interim Safety Basis } \\ \text { LFL } & \text { Lower Flammability Limit } \\ \text { LOW } & \text { Liquid Observation Well } \\ \mu m & \text { Micrometers } \\ \text { MIT } & \text { Multifunctional Instrument Tree } \\ \text { NEPA } & \text { National Environmental Policy Act } \\ \text { NIR } & \text { Near Infrared } \\ \text { PNL } & \text { Pacific Northwest Laboratory } \\ \text { ppm } & \text { Parts Per Million } \\ \text { RSST } & \text { Reactive Systems Screening Tool (small adiabatic calorimeter at FAI) } \\ \text { SA } & \text { Safety Assessment } \\ \text { SAR } & \text { Safety Analysis Report } \\ \text { SD } & \text { Supporting Document } \\ \text { SRL } & \text { Savannah River Laboratory } \\ \text { SST } & \text { Single-Shell Tank } \\ \text { TC } & \text { Thermocouple } \\ \text { TMACS } & \text { Tank Monitor and Control System } \\ \text { TPA } & \text { Tri-Party Agreement, Hanford Federal Facility Agreement } \\ \text { USQ } & \text { Und Consent Order } \\ \text { VSP } & \text { Vent Sizing Package (large adiabatic calorimeter at FAI) } \\ & \end{array}$


WHC-EP-0474-12

This page intentionally left blank. 


\subsection{INTRODUCTION}

\subsection{PURPOSE}

This quarterly report provides a status of the activities underway at the Hanford Site on the Ferrocyanide Safety Issue, as requested by the Defense Nuclear Facilities Safety Board (DNFSB) in their Recommendation 90-7 (FR 1990). In March 1991, a DNFSB implementation plan (Cash 1991) responding to the six parts of Recommendation 90-7 was prepared and sent to the DNFSB. The implementation plan was updated in FY 1993 (Borsheim et al. 1992). A revised Ferrocyanide Safety Program Plan addressing the total Ferrocyanide Safety Program, including the six parts of DNFSB Recommendation 90-7, was recently prepared and released in March 1994 (Borsheim et al. 1994). Activities in the revised program plan are underway or have been completed, and the status of each is described in Section 4.0 of this report.

\subsection{QUARTERLY HIGHLIGHTS}

- The Ferrocyanide Unreviewed Safety Question (USQ) was closed on March 1, 1994 by the U.S. Department of Energy's (DOE) Assistant Secretary for Environmental Restoration and Waste Management (Sheridan 1994). This action satisfied the accelerated Safety Initiative (2s) and Tri-Party Agreement (TPA) (M-40-14) milestones.

- DOE comments were incorporated into ferrocyanide safety criteria document, and the document was publicly released this quarter (Postma et al. 1994). A Ferrocyanide USQ screening was performed and an engineering change notice, incorporating the safety criteria, was written for the Hanford Site Tank Farm Facilities Interim Safety Basis (ISB) (Wagoner 1993). These documents provided the basis for closure of the Ferrocyanide USQ.

- Review comments on the Ferrocyanide Safety Program plan were incorporated and the document was released this quarter (Borsheim et al. 1994). The program plan describes all current and anticipated work in the Ferrocyanide Safety Program. Schedules showing program activities leading to eventual Safety Issue resolution by fiscal year (FY) 1997 are presented in the program plan. Work in the Ferrocyanide Safety Program is reported against the new program plan on a quarterly basis (see Section 5.0 for schedules and work status).

- The generic Environmental Assessment (EA), covering tank farm operations (including installation of instrument trees into assumed leaker ferrocyanide tanks and rotary core sampling), was approved this quarter, and a Finding of No Significant Impact was issued by the U.S. Department of Energy. Approval of the generic EA eliminates the need prepare additional EAs and streamlines the approval process. The generic EA 
provides adequate National Environmental Policy Act (NEPA) coverage for the planned Ferrocyanide Safety Program activities.

- A draft document was prepared this quarter describing criteria for upgraded temperature monitoring capabilities in ferrocyanide tanks. The report concludes that one instrument tree is sufficient to monitor temperature in the ferrocyanide tanks, given the current knowledge of the ferrocyanide hazard. This document addresses a recently established TPA milestone (M-40-02A) due in September 1994.

- New information on thermal conductivity of the soils surrounding the waste tanks was incorporated into the heat load model. Thermal conductivity data from soil analyses revealed that conductivity values are greater than those used previously. Tank heat load estimates using the new thermal conductivity data are consistent with other independent estimates (Borsheim and Simpson 1991, Crowe et al. 1993).

- A draft report evaluating possible sources of flammable gases, including potential cyclic venting, was prepared this quarter. The report concludes that continuous vapor monitoring for flammable gases in ferrocyanide tanks is not warranted. The draft study report is undergoing technical review by Westinghouse Hanford Company, DOE, and Washington State Department of Ecology. The document is scheduled for public release next quarter.

- A preliminary study was released this quarter on remote Fourier Transform infrared (FTIR) spectroscopy techniques being considered for in situ and/or hot cell ferrocyanide applications (Rebagay et al. 1994). In general, the spectra obtained using the remote systems resembled those collected from the same waste using conventional FTIR sampling accessories.

- Two aging experiments were completed this quarter. In Farm ferrocyanide waste simulant was mixed with two molar sodium hydroxide and exposed to gamma irradiation for three weeks at 70 and $90^{\circ} \mathrm{C}$. Results show that the rate ferrocyanide destruction is temperature dependent. At $90^{\circ} \mathrm{C}\left(194^{\circ} \mathrm{F}\right)$ approximately $60 \%$ of the cyanide groups were hydrolyzed, and at $70^{\circ} \mathrm{C}\left(158^{\circ} \mathrm{F}\right)$, less than $5 \%$ of the cyanide groups were hydrolyzed.

- Propagation tests on dry ferrocyanide waste simulant mixtures showed that the minimum fuel concentration necessary to support propagating reactions is between 13 and $14 \mathrm{wt} \%$ [as $\mathrm{Na}_{2} \mathrm{NiFe}(\mathrm{CN})_{6}$ ]. The test conducted at $14 \mathrm{wt} \%$ propagated at a very low rate, while the two tests conducted at 12 and $13 \mathrm{wt} \%$ did not propagate.

- A report on the T Plant calorimetry and propagation tests conducted earlier was publicly released this quarter (Epstein et al. 1994). The report concludes that $T$ Plant simulant does not support a propagating reaction. 
- A report on the conditions necessary for ferrocyanide - nitrate/nitrite propagation was released this quarter (Fauske and Jeppson 1994). The report describes fuel and moisture requirements for supporting a propagating reaction.

\subsection{REPORT FORMAT}

Progress of activities under each of the six parts of DNFSB Recommendation 90-7 are arranged in the same order as the program plan (Borsheim et al. 1994). The arrangement also follows the same order provided in the recommendation. To report on progress, each part of the recommendation is repeated in italics, followed by paragraphs explaining the scope of work on each part or subpart of the recommendation. Subheadings for each task activity report the following:

- Progress During Reporting Period

- Planned Work for Subsequent Months

- Problem Areas and Action Taken

- Milestone Status. 


\section{WHC-EP-0474-12}

This page intentionally left blank. 


\subsection{BACKGROUND}

Various high-level radioactive waste from defense operations has accumulated at the Hanford Site in underground storage tanks since the mid-1940s. During the $1950 \mathrm{~s}$, additional tank storage space was required to support the defense mission. To obtain this additional storage volume within a short time period, and to minimize the need for constructing additional storage tanks, Hanford Site scientists developed a process to scavenge ${ }^{137} \mathrm{Cs}$ from tank waste liquids. In implementing this process, approximately 140 metric tons (154 tons) of ferrocyanide were added to waste that was later routed to some Hanford Site single-shell tanks (SSTs).

Ferrocyanide, in the presence of oxidizing material such as sodium nitrate and/or nitrite, can react exothermically in the laboratory by heating it to high temperatures or by an electrical spark of sufficient energy. Under laboratory conditions deliberately created to enhance the potential for reactions, significant exothermic reactions can start as low as $220^{\circ} \mathrm{C}\left(430{ }^{\circ} \mathrm{F}\right)$, but the lowest propagation temperature observed is approximately $250^{\circ} \mathrm{C}\left(480^{\circ} \mathrm{F}\right)$. The reactive nature of ferrocyanide in the presence of an oxidizer has been known for decades, but the conditions under which the compound can undergo endothermic and exothermic reactions have not been thoroughly studied. Because the scavenging process precipitated ferrocyanide from solutions containing nitrate and nitrite, an intimate mixture of ferrocyanides and nitrates and/or nitrites is likely to exist in some regions of the ferrocyanide tanks.

Efforts have been underway since the mid-1980s to evaluate the potential for ferrocyanide reactions in Hanford Site SSTs (Burger 1989, Burger and Scheele 1988). The potential consequences of a postulated ferrocyanide reaction were not evaluated in the safety analyses or safety analysis reports (SARs) applicable to the Hanford Site SSTs. The SARs historically have considered a rapid exothermic reaction from fuel/nitrate reactions as an incredible event, and the consequences of incredible events are not required to be analyzed (WHC 1992).

Although not considered a part of the safety analysis for storage of waste in the SSTs, the 1987 Environmental Impact Statement (EIS), Final Environmental Impact Statement, Disposal of Hanford Defense High-Level Transuranic and Tank Waste, Hanford Site, Richland, Washington (DOE 1987) did include an environmental impact analysis of potential exothermic reactions involving ferrocyanide-nitrate mixtures. The EIS speculated that an explosion could occur during mechanical retrieval of saltcake or sludge from a ferrocyanide waste tank. The EIS authors concluded that this worst-case accident could create enough energy to release radioactive material to the atmosphere through ventilation openings, exposing persons offsite to a short-term radiation dose of approximately 200 mrem. A General Accounting Office (GAO) study (Peach 1990) postulated a greater worst-case accident, with independently calculated doses of one to two orders of magnitude greater than in the EIS. Coupling the ferrocyanide concerns with concerns about high organic concentrations and potential hydrogen accumulations in other Hanford Site high-level waste tanks, the DOE established the High-Level Radioactive Waste Tanks Task Force and Tanks 
Advisory Panel in August 1990. These two groups were formed to ensure that all safety concerns with high-level waste tanks at DOE sites are identified and addressed in a systematic and timely manner.

The initial focus of the task force and advisory panel was on the Hanford Site Flammable Gas and Ferrocyanide Safety Issues. In September 1990, a special Hanford Site ferrocyanide task team was commissioned by Westinghouse Hanford Company to address all issues involving the ferrocyanide tanks, including the consequences of a potential accident.

The Ferrocyanide Safety Issue is a result of a combination of factors, beginning with the safety studies performed as precursors to using the ferrocyanide scavenging flowsheets. These studies did not address ultimate disposal of the ferrocyanide solids, and were not performed to the conservative standards used today. In addition, no rigorous inventory was kept of the ferrocyanide or other chemicals added to the tanks. Subsequent safety studies determining the risk of adding other chemicals were either not performed, or were performed to less conservative standards. Monitoring systems, such as temperature measurement instrumentation, were allowed to be disconnected and fall into disrepair because the potential hazard was not highlighted.

Although the EIS estimated the consequences from a hypothetical explosion, the GAO disagreed with the assumptions used for the dose consequence calculations. Work performed by Pacific Northwest Laboratory (PNL) in 1984-85 identified a potential safety problem, but no funding was provided until 1989 to study this Safety Issue. An additional issue was subsequently communicated about the assumed radioactive material source term (release fraction) resulting from a hypothetical explosion (Peach 1990).

In October 1990 (Deaton 1990), the Ferrocyanide Safety Issue was declared a USQ because the safety envelope for these tanks was no longer bounded by the existing safety analysis report (RHO 1986). In 1991, using process knowledge, process records, transfer records, and $\log$ books, 24 Hanford Site tanks were identified as potentially containing $1,000 \mathrm{~g}$-moles $(465 \mathrm{lb})$ or more of ferrocyanide [as the $\mathrm{Fe}(\mathrm{CN})_{6}^{4}$ anion]. These tanks were placed on a Ferrocyanide Watch List because of the USQ. Re-examination of the historical records (Borsheim and Simpson 1991) indicated that 6 of the 24 tanks do not contain the requisite

'An Unreviewed Safety Question, as defined by DOE Orders 5480.5 (DOE 1986) and 5480.21 (DOE 1991), is determined as follows. "A proposed change, test or experiment shall be deemed to involve an USQ if the following apply:

a. The probability of occurrence or the consequences of an accident or malfunction of equipment important to safety, evaluated previously by safety analysis will be significantly increased, or

b. A possibility for an accident or malfunction of a different type than any evaluated previously by safety analysis will be created which could result in significant safety consequences." 
$1,000 \mathrm{~g}$-moles of ferrocyanide and should not have been included on the Watch List. Four of the 6 tanks were removed from the Watch List in June 1993 (Meacham et al. 1993) and removal of the other two tanks is pending (Borsheim et al. 1993).

The Ferrocyanide USQ was closed on March 1, 1994 by the DOE Assistant Secretary for Environmental Restoration and Waste Management. Closure of the Ferrocyanide USQ was based on safety criteria proposed by Westinghouse Hanford Company and concurred on by outside reviewers and reviewers within DOE. This was the first USQ closure in the current Waste Tank Safety Program since the Watch List was created in 1990. 
t-z

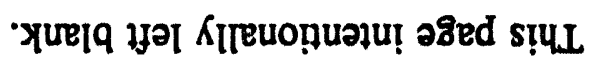




\subsection{FERROCYANIDE SAFETY DOCUMENTATION}

The USQ process depends on an authorization basis that describes those aspects of the facility design basis and operational requirements relied on by DOE to authorize operation. The authorization basis is described in documents such as facility SARs and other safety analyses, hazard classification documents, technical safety requirements, DOE issued safety evaluation reports, and facility-specific commitments, such as Safety Assessments (SAs) and the ISB (Wagoner 1993). The potential hazards of a ferrocyanide-nitrate/nitrite reaction were discovered to represent an inadequacy in the authorization basis.

A strategy for closing the USQ and resolving the Safety Issue for the ferrocyanide waste tanks was developed by DOE and Westinghouse Hanford Company and presented to the DNFSB in August 1993 (Grumbly 1993). The strategy contains two key steps:

(1) developing criteria for safety categories that rank the hazard for each tank, allowing closure of the USQ, and (2) confirmation and final placement of each tank into one of the categories based on core sampling and characterization of the tank contents.

Closure of the Ferrocyanide USQ. DOE comments were incorporated into the ferrocyanide safety criteria document, and the report was publicly released this quarter (Postma et al. 1994). A Ferrocyanide USQ screening was performed and an engineering change notice, incorporating the safety criteria, was written for the ISB. Based on this documentation, a formal request to close the USQ was made by Westinghouse Hanford Company in January (Alumkal 1994). The Ferrocyanide USQ was closed on March 1, 1994 by the DOE Assistant Secretary for Environmental Restoration and Waste Management (Sheridan 1994). Closure of the USQ completes accelerated Safety Initiative milestone $2 \mathrm{~s}$ and TPA milestone M-40-14.

Ferrocyanide Safety Program Plan. Review comments on the Ferrocyanide Safety Program plan were received from DOE. The comments were incorporated and the document was released this quarter (Borsheim et al. 1994). The program plan describes all the current and anticipated work in the Ferrocyanide Safety Program. Schedules showing program activities leading to eventual Safety Issue resolution by FY 1997 are presented in the program plan. Work in the Ferrocyanide Safety Program is reported against the new program plan on a quarterly basis (see Section 5.0 for schedules and work status).

Safety and Environmental Assessments. SAs are documents prepared to provide the technical basis to assess the safety of a proposed activity and to provide proper controls to maintain safety. The SA and the accompanying EA for that operation provide the basis for DOE authorization of the proposed activities. The authorization basis for previously analyzed intrusive tank operations was combined into one document, the ISB, which was approved by DOE in November 1993 (Wagoner 1993).

SAs have been completed for vapor space sampling of all ferrocyanide tanks, waste surface sampling, push-mode core sampling, thermocouple (TC)/instrument tree installation in sound tanks, and removal of pumpable liquid (interim stabilization). SAs for rotary-mode core 
sampling and instrument tree installation in assumed leaker tanks were approved by DOE this quarter.

The EA for installation of instrument trees into the 11 assumed leaker ferrocyanide tanks was incorporated into the generic EA covering operations for Watch List tanks. The generic EA was approved this quarter and a Finding of No Significant Impact was issued by DOE. Approval of the generic EA provides adequate NEPA coverage for the planned Ferrocyanide Safety Program activities and streamlines the approval process.

Hazard Assessment. The effort to update the ferrocyanide hazards assessment document was redirected in June 1993 toward developing a technical basis document supporting resolution of the Ferrocyanide Safety Issue. An updated ferrocyanide hazards assessment, now referred to as a technical basis document, will not be started until adequate information is available for resolving the Ferrocyanide Safety Issue. Technical information from all Ferrocyanide Safety Program tasks will be incorporated into this document. This document may be necessary to support Safety Issue resolution for the four C Farm tanks in FY 1995. An update of the document may be necessary in FY 1997 to support Safety Issue resolution for the remaining 14 tanks.

Dose Consequences. In September 1990, an Ad Hoc Task Force report recommended that studies be performed to provide information on: (1) the potential for a ferrocyanidenitrate/nitrite explosion; (2) the conditions necessary in the tanks to initiate an explosion; and (3) the potential consequences of such an occurrence. The GAO advised the Secretary of Energy to implement these recommendations. Documentation prepared addressing recommendations (1) and (2) has shown that the risk for a ferrocyanide explosion is incredible. Because consequences of incredible events do not have to be analyzed (WHC 1992), there exists limited technical justification for completion of a consequence report. Therefore, the need for dose consequence experiments and analyses is being re-evaluated.

\section{- Milestone Status}

- December 1, 1993: Submit, for DOE review, a draft ferrocyanide safety criteria document that defines safe storage of ferrocyanide waste. This milestone was completed on schedule, and a publicly available document was released in January 1994 (Postma et al. 1994).

- December 17, 1993: Submit an update of the Ferrocyanide Safety Program plan to DOE for approval. This milestone was completed on schedule, and the document was publicly released in March 1994 (Borsheim et al. 1994).

- January 31, 1993: Receive DOE approval to close the Ferrocyanide USQ (Safety Initiative 2s). The Ferrocyanide USQ was closed on March 1, 1994 (Sheridan 1994). A letter was sent on March 30, 1994 (Wisness 1994) informing the U.S. Environmental Protection Agency and State of 
Washington Department of Ecology that TPA milestone M-40-14 (closure of the Ferrocyanide USQ by March 31, 1994) was completed.

- June 24, 1994: Issue an ISB Level 1 report to DOE that provides the safety basis for safe operation of ferrocyanide tanks.

- July 29, 1994: Issue an update of the ferrocyanide hazards assessment document. This milestone was deferred to FY 1995 and may be canceled if not required to resolve the Safety Issue for the four C Farm tanks.

- August 31, 1995. Issue technical basis document supporting Safety Issue resolution for $\mathrm{C}$ Farm tanks, if required. Recommend Safety Issue resolution for C Farm tanks.

- February 29, 1996. Obtain DOE approval to remove C Farm tanks from the Watch List. Safety Issue resolved for C Farm tanks.

- January 31, 1997. Revise technical basis document to support Safety Issue resolution for the remaining 14 tanks, if required. Recommend Safety Issue resolution for all tanks.

- September 30, 1997. Receive DOE approval to remove all tanks from the Ferrocyanide Watch List. This action resolves the Ferrocyanide Safety Issue. 
WHC-EP-0474-12

This page intentionally left blank. 


\subsection{DESCRIPTION OF ACTIVITIES}

This section follows the format of the program plan (Borsheim et al. 1994) and describes all work associated with the Ferrocyanide Safety Program. Where applicable, each task activity is described relative to the DNFSB Recommendation (90-7.1 through 90-7.6). The specific recommendation is given, followed by a summary of activities underway to respond to the recommendation (if not already closed out).

\subsection{ENHANCED TEMPERATURE MEASUREMENT}

"Immediate steps should be taken to add instrumentation as necessary to the SSTs containing ferrocyanide that will establish whether hot spots exist or may develop in the future in the stored waste. The instrumentation should include, as a minimum, additional thermocouple trees. Trees should be introduced at several radial locations in all tanks containing substantial amounts of ferrocyanide, to measure the temperature as a function of elevation at these radii. The use of infrared techniques to survey the surface of waste in tanks should continue to be investigated as a priority matter, and on the assumption that this method will be found valuable, monitors based on it should be installed now in the ferrocyanide bearing tanks."

\subsubsection{Instrument Trees}

A strategy initially was developed to provide the temperature instrumentation necessary to monitor conditions in five high-concern waste tanks on an expedited basis. The strategy was to: (1) repair the existing TC elements (where possible); (2) install new instrument trees that would be fabricated from existing drawings; and (3) install multifunctional instrument trees (MITs) in those tanks that only have a few risers available. The MITs would provide temperature monitoring, the capability for gas sampling at three elevations, possible pressure monitoring, and access for deployment of fiber optics inside the tanks, if desired. The instrument trees would provide temperature monitoring but may not provide the option to obtain any other needed data.

This strategy was later revised to include only repair of TC elements in existing trees and installing new instrument trees in ferrocyanide waste tanks. A number of uncertainties concerning surveillance requirements were experienced with the early design and development of the MITs. Resolution of design and operational requirements resulted in substantial schedule delays and cost incr...ses. In an effort to expedite the required ferrocyanide tank temperature measurement upgrades, it was decided to: 1) fabricate and install instrument trees in the tanks; and 2) determine how to take gas samples from the vapor space at a later date, if the installed capability for taking periodic or continuous gas samples is determined to be necessary. Currently, there are no plans to install MITs in the ferrocyanide tanks. 
- Progress During Reporting Period. Four instrument trees with heated vapor sampling tubes have been fabricated for insertion into four assumed leaker ferrocyanide tanks. Installation of ultra high-pressure bore heads on the new instrument trees was completed this quarter. All equipment and safety documentation supporting insertion of the trees are in place and installation will begin next quarter.

A draft document was prepared this quarter describing criteria for upgraded temperature monitoring capabilities in ferrocyanide tanks. The report concludes that one instrument tree is sufficient to monitor temperature in the ferrocyanide tanks, given the current knowledge of the ferrocyanide hazard. The document is currently undergoing review at Westinghouse Hanford Company, DOE, and Washington State Department of Ecology. It is scheduled for public release in September 1994. This document addresses a recently established TPA milestone (M-40-02A).

- Planned Work for Subsequent Months. Instrument trees will be installed into four assumed leaker tanks (241-BY-107, -108, 241-C-111, and 241-TY-104) and four additional instrument trees will be fabricated.

- Problem Areas and Action Taken. None.

- Milestone Status.

- September 30, 1994: Install nine instrument trees into assumed leaker ferrocyanide tanks. This milestone also addresses the September 1994 TPA milestone (M-40-02B), installation and operation of six instrument trees in ferrocyanide tanks.

- September 30, 1994: Develop criteria for upgraded temperature monitoring capabilities in ferrocyanide tanks (TPA milestone M-40-02A).

- December 31, 1994: Complete installation of instrument trees in assumed leaker tanks. Replace temperature sensing elements in the remaining two ferrocyanide tanks as necessary.

\subsubsection{Upgrades to Existing Temperature Monitoring Instrumentation}

This task determiried the operability and accuracy of previously installed TC elements in the original 24 Ferrocyanide Watch List tanks. The original and newly installed TCs now provide temperature measurements for the ferrocyanide tanks.

Field measurements were taken in 1991 on each TC element in the then-existing trees to determine the resistance and voltage across the junction and across each lead to ground. The 
exact condition of each TC was determined by resistance and voltage measurements (Bussell 1992). This work was completed in FY 1991 with a total of 265 TCs being evaluated. Work in FY 1992 focused on repair and recovery of 92 TCs that were found to be failed or marginal in performance. This task was completed in FY 1992.

- Progress During Reporting Period. No progress was required or planned.

- Planned Work for Subsequent Months. None.

- Problem Areas and Actions Taken. None.

- Milestone Status. This task is complete.

\subsubsection{Hot Spot Thermal Modeling}

Radioactive materials decaying in Hanford Site waste tanks generate heat. A concern, raised when the ferrocyanide tanks first became a safety issue, has been whether an exothermic excursion and local propagation could occur within the ferrocyanide waste if there was a sufficient concentration of ferrocyanide and a high enough temperature present. There are usually only one or two instrument trees in each ferrocyanide tank, and the trees are not always at the same location. Consequently, it is questionable whether abnormal heat generation could exist in these tanks and not be detected. 'This task models and analyzes the available temperature data from the ferrocyanide tanks in order to determine the heat load and temperatures as a function of depth and radial location. Sensitivity and parametric analyses are included to determine the magnitude of hot spots that would have to exist within the waste to reach propagation temperatures.

State-of-the-art validated computer codes are used in the modeling. They are benchmarked with existing data and employ two- and three-dimensional capabilities. Both steady-state and transient models are used. The intent of this work is to determine accurate heat loads for each ferrocyanide tank and to model hypothetical hot spots.

- Progress During the Reporting Period. Development of an improved model for thermal analysis of the ferrocyanide waste storage tanks was completed last quarter. The model was used to estimate the heat loads and thermal conductivities of tanks 241-BY-103, -105, -106, and -107. New information on thermal conductivity of the soils surrounding the waste tanks, under various conditions of temperature and moisture, was recently obtained and incorporated into the heat load model. Soil analyses revealed that the conductivity values are greater than those used previously. Tank heat load estimates using the new conductivity data are consistent with estimates made from other independent sources (Borsheim and Simpson 1991, Crowe et al. 1993). This is of interest because each method uses different techniques, providing a check on the heat load estimates. 
- Planned Work for Subsequent Months. The updated thermal heat transfer/heat load model will be used to analyze the heat load and thermal characteristics of all ferrocyanide tanks. Two reports on these analyses will be prepared and issued later in FY 1994.

The dryout position paper (Dickinson et al. 1993) will be updated to include discussion on additional dryout mechanisms. The revised report will be released next quarter.

- Problem Areas and Action Taken. None.

- Milestone Status.

- May 31, 1994. Complete additional analyses and issue an update of the report Ferrocyanide Safety Program: Credibility of Drying out Ferrocyanide Waste by Hot Spots (Dickinson et al. 1993), approved for public release.

- June 30, 1994. Complete thermal hydraulic analyses of heat loads for nine ferrocyanide tanks (241-BY-103, -105, -106, -107, -108, -110, -111, and 241-C-109 and -112) and issue a report available to the public.

- September 30, 1994. Complete thermal hydraulic analyses of heat loads for all remaining ferrocyanide tanks and issue a report available to the public.

\subsubsection{Infrared Scanning System}

Infrared (IR) scanning systems are commercially available from numerous vendors. These systems are sensitive to changes of $\pm 0.3^{\circ} \mathrm{C}\left(0.5^{\circ} \mathrm{F}\right)$ or less under ideal conditions, and offer promise for mapping surface temperature profiles in the ferrocyanide tanks. Thermal modeling performed on ferrocyanide tank 241-BY-104 suggested that, if hot spots with temperatures of concern are possible, surface temperature differences might be great enough to be detected by infrared mapping.

A position paper on the credibility of hot spots and the need for further IR scanning was completed and issued in April 1993 (Dickinson et al. 1993). This paper examined potential concentration mechanisms and determined the degree of concentration required to produce temperatures high enough to dry the ferrocyanide waste. The paper concluded that such concentrations were incredible. Based on this report, Westinghouse Hanford Company recommended that no further planning be pursued for IR scans for the purpose of detecting hot spots. 
- Progress During the Reporting Period. None.

- Planned Work for Subsequent Months. A draft report on the infrared scans of tank 241-S-110, Application of Infrared Imaging in Ferrocyanide Tanks, (WHC-EP-0593) was submitted to DOE in January 1993.

- Problem Areas and Action Taken. None.

- Milestone Status. None.

\subsection{CONTINUOUS TEMPERATURE MONITORING}

"The temperature sensors referred to above [Recommendation 90-7.1] should have continuous recorded readouts and alarms that would signal at a permanently manned location any abnormally high temperatures and any failed temperature instrumentation."

This task will provide continuous monitoring of presently installed (and operable) TCs for the ferrocyanide tanks. New instrument trees will be connected to the system as they are installed into each tank, resulting in continuous monitoring of temperature in the ferrocyanide tanks. All data are collected automatically at the continuously manned Computer Automated Surveillance System (CASS) Operator Control Station. The monitoring system is independent of the CASS and capable of displaying data to an operator on request. Trend data on selected points are available for display in numeric or graphic form.

The system, which became operational in September 1991, has the capacity to assign alarms for a change in the value of any temperature point. Alarms, if they occur, trigger an audible annunciator and are logged immediately to hard copy. An alarm summary display provides a list of the most recent alarms in order of occurrence. Each alarm can be identified by point and time of occurrence. Operator acknowledgement of the alarm will silence the audible annunciator.

Signal conditioning and multiplexing are performed locally at each tank. This eliminates the need to transmit low-level signals to the tank farm boundary and reduces cable runs. Electronic noise, extension wire corrosion, and thermal gradients are also reduced.

Five BY Farm tanks were connected to the system in September 1991; an additional five were connected in December 1991. These tanks include 241-BY-101 (now removed from Watch List), 241-BY-103, -104, -105, -106, -107, -108, -110, -111, and -112. Tank 241-BY-105 already had two operating TC trees. Both were connected to the Tank Monitor and Control System (TMACS). In April 1992, tanks 241-TY-101, -103, -104, and 241-TX-118 were connected to the system and are now operational. Four new instrument trees installed in tanks 241-BY-104, $-110,-111$, and -112 have been connected to TMACS. This makes a total of 13 ferrocyanide tanks [16 trees and two liquid observation wells 
(LOWs)] that are now monitored by TMACS. Temperature readings from the working TC elements in these tanks are being recorded continuously.

- Progress During Reporting Period. Construction resumed for connection of TMACS in C and BX Farms. A work package is being prepared for T Farm installation and all design work for these farms is now complete.

- Planned Work For Subsequent Months. Installation of TMACS in C and BX Farms will be completed and work will resume in $\mathrm{T}$ Farm.

- Problem Areas and Action Taken. A shortage of trained personnel for construction exists because of reassignment during the Administrative Hold. Additional personnel are being trained to meet the need for TMACS connections.

- Milestone Status.

- September 30, 1994. Complete installation of TMACS for the four ferrocyanide tanks in C Farm, one tank in T Farm, and two tanks in BX Farm. Ferrocyanide tanks removed from the Watch List (241-BX-110, 241-BY-101, and 241-T-101), or pending removal (241-BX-102 and -106) from the Watch List, will be connected in FY 1995.

- December 31, 1994. Complete installation of TMACS for new instrument trees installed in FY 1994. The completion of TMACS installations is also a TPA milestone (M-40-02).

\subsection{COVER GAS MODELING}

"Instrumentation should also be installed to monitor the composition of cover gas in the tanks, to establish if flammable gas is present."

\subsubsection{Interim Flammable Gas Monitoring}

The effort to conduct flammable and toxic gas monitoring and analyses in the ferrocyanide tanks is continuing. Most of this effort was transferred to the Tank Vapor Issue Resolution Program, which is coordinating interim gas monitoring of the ferrocyanide tanks, as well as those tanks involved with the tank vapor safety issue. Tank vapor spaces are measured for flammability using a commercial combustible gas monitor (calibrated with pentane gas), and are monitored for potential toxic gases using an organic vapor monitor and Dräger ${ }^{2}$ tubes as required by the safety assessment and work procedures for a particular activity.

Development and validation of alternative technologies for vapor space characterization are in

\footnotetext{
${ }^{2}$ Trademark of National Draeger, Inc., Pittsburgh, Pennsylvania.
} 
progress using Summa canisters and specific absorption tubes. The initial vapor space sampling was done in several tank locations (i.e., from two widely separated risers) and at three elevations in the vapor space. Review of the sample data indicated that sampling from one riser was adequate; the number of sample elevations may be reduced in the future.

To date, the vapor space in 11 tanks on the Ferrocyanide Watch List have been sampled. In one of the tanks, the combustible gas analyzer reading was reported as one percent of the lower flammability limit (LFL) and all the other ferrocyanide tanks sampled contained < $1 \%$ of the LFL. The maximum reading for organic vapor was 350 parts per million (ppm), $\sim 0$. 035 vol\%, in tank 241-BY-110, and all other tanks had readings at least an order of magnitude lower. Ammonia was detected in several of the sampled tanks; the maximum reported value was estimated as $612 \mathrm{ppm}$, again in tank 241-BY-110. The measured values in the other tanks ranged from $<2 \mathrm{ppm}$ to $250 \mathrm{ppm}$. Hydrogen cyanide measurements with Dräger ${ }^{\mathrm{TM}}$ tube monitoring were all below $2 \mathrm{ppm}$ (the detection limit for that method). Two tanks, 241-C-108 and -111, were analyzed with a more sensitive method, and hydrogen cyanide concentrations were less than 0.04 parts per billion (i.e., $<40$ parts per trillion). Table A-2 in Appendix A reviews gas analyses for the ferrocyanide tanks sampled to date.

- Progress During Reporting Period. No core sampling or instrument tree installation was performed this quarter. Therefore, there was no need for gas monitoring to support these activities and no additional ferrocyanide tank vapor space samples were taken.

- Planned Work For Subsequent Months. Flammable gas sampling and selected noxious gas monitoring will continue, as required, to support planned core sampling and instrument tree installation. This work will resume next quarter to support core sampling and instrument tree installation.

- Problem Areas and Actions Taken. None.

- Milestone Status

- September 30, 1994. Complete vapor space sampling of remaining ferrocyanide tanks, as required, to support various field activities.

- September 30, 1995. Complete vapor space sampling of remaining ferrocyanide tanks. This milestone addresses the November 1995 TPA milestone $\mathrm{M}-40-03$.

\subsubsection{Continuous Gas Monitoring}

Options for installing a gas monitoring capability on new instrument trees have been reviewed and a heated vapor sampling tube has been added to the design of future instrument trees for ferrocyanide tanks. These modifications will allow vapor space sampling 
on a continuous or intermittent basis. The need for continuous gas monitoring is being addressed in a study that also addresses the potential for cyclic venting and the possibility of accumulating flammable gases.

The possibility that localized concentrations or stratification of gases exist in the tanks has been evaluated. A modeling study to determine airflow patterns in the vapor space of tank 241-C-109 was conducted to evaluate the amount of mixing and the local gas concentrations that could occur. The study revealed that the gases in the tank are well mixed and follow Graham's law for gaseous diffusion; therefore, an analysis of a second tank was considered unnecessary because of the well-mixed environment calculated for 241-C-109 (Wood 1993).

- Progress During Reporting Period. A draft report evaluating possible sources of flammable gases, including potential cyclic venting, was prepared this quarter. The report concludes that continuous flammable gas monitoring in ferrocyanide tanks is not warranted based on: (1) evaluation of tank vapor sample results to date showing no more than 1\% of the LFL; (2) consideration of waste simulant aging studies indicating that the ferrocyanide has degraded in the tanks and is no longer present in flowsheet concentrations; (3) evaluation of core sample results from tanks 241-C-109 and -112 showing that the fuel concentration in the tanks is not as high as postulated by flowsheet simulants; and (4) new calculations of hydrogen generation using realistic $\mathbf{G}$ values and passive ventilation assumptions. The draft report is undergoing technical review by Westinghouse Hanford Company and DOE and will be publicly released next quarter.

- Planned Work For Subsequent Months. Comments from Westinghouse Hanford Company and DOE reviewers will be incorporated into the continuous gas monitoring report.

- Problem Areas and Actions Taken. None.

- Milestone Status.

- March 31, 1994: Complete an evaluatiun report to determine which gases, if any, need to be continuously monitored in selected ferrocyanide tanks. A draft report was completed this quarter and will be prepared for public release next quarter.

- September 30, 1995: Develop and design continuous monitoring equipment, if required.

- September 30, 1997: Install continuous gas monitoring equipment in six tanks, if required. 


\subsubsection{Tank Pressure Monitoring}

Public Law 101-510 (1990) (Section 3137 - also known as the Wyden Amendment) requires that "... the Secretary of Energy shall identify which single-shell tanks ... may have a serious porental for release of high-level waste due to uncontrolled increases of ... pressure. After completing such identification, the Secretary shall determine whether continuous monitoring is being carried out to detect a release or excessive ... pressure at each tank so identified. If such monitoring is not being carried out, as soon as practicable the Secretary shall install such monitoring...."

The ferrocyanide tanks were initially identified as having "a serious potential for release" and were placed on the Watch List; however, pressure monitoring capability does not presently exist for the tanks. It would take several years for pressure monitoring instrumentation to be installed and connected to a continuously manned location, because of the capital project time cycle. Sufficient knowledge on the safety of the Ferrocyanide Watch List tanks exists at this time such that the USQ has been closed (see Section 4.0). Because of waste aging, it is possible that all of the ferrocyanide tanks may now contain less than the 8 wt\% sodium nickel ferrocyanide specified in the fuel criterion for the SAFE category. It is anticipated that characterization (core sampling and data interpretation) may place all of the tanks into the SAFE category, because of the low fuel value remaining. Placement of the tanks into the SAFE category means the tanks are candidates for removal from the ferrocyanide Watch List. This would eliminate the need for continuous pressure monitoring for off-gases from a ferrocyanide reaction.

- Progreas During Reporting Period. A study is being conducted that will evaluate the potential for the generation of gases that might cause pressurization of a ferrocyanide tank. Based on the results of this study, a recommendation will be made on the need for installing pressure monitoring equipment.

- Planned Work For Subsequent Months. Complete the evaluation of potential gas generation in ferrocyanide tanks and determine the need for continuous pressure monitoring.

- Millestone Status.

- July 29, 1994. Complete studies to determine whether continuous pressure monitoring is required for some or all ferrocyanide tanks.

- September 30, 1995. Install the first phase of pressure monitoring instrumentation, if required.

- September 30, 1996. Install pressure monitoring instrumentation and readout capability on all applicable ferrocyanide tanks, if required. 


\subsection{FERROCYANIDE WASTE CHARACTERIZATION}

"The program of sampling the contents of these tanks should be greatly accelerated. The proposed schedule whereby analysis of two core samples from each single-shell tank is to be completed by September 1998 is seriously inadequate in light of the uncertainties as to safery of these tanks. Furthermore, additional samples are required at several radit and at a range of elevations for the tanks containing substantial amounts of ferrocyanide."

Characterization of the waste in the ferrocyanide tanks is necessary to: (1) guide further chemical reaction studies with the ferrocyanide waste simulants; (2) determine actual waste chemical and physical properties; (3) determine how the ferrocyanide waste can be safely stored in situ, and classify the tanks by safety category accordingly, until retrieval and disposal actions are completed; and (4) apply the study results to the final remediation of the waste. This information is necessary to resolve the Ferrocyanide Safety Issue.

The important reactive materials present in the ferrocyanide tanks are fuel (ferrocyanides, sulfides, and reduced carbon species such as organic complexants), oxidants (nitrates and nitriter), and inerts or diluents (including phosphates, aluminates, sulfates, carbonates, oxides, and hydroxides). The location of fission products such as ${ }^{137} \mathrm{Cs}$ and ${ }^{90} \mathrm{Sr}$ is important because these products are heat sources and potential source terms in postulated radiological releases from a hypothetical ferrocyanide reaction. The water content of the waste is very important because water's high heat capacity and vaporization heat make it an effective inerting material. Water content can prevent a sustained combustion or a propagating reaction; wet ferrocyanide material would require drying before it could react or propagate.

\subsubsection{Core Sampling and Analyses}

Core Sampling. The current schedule for waste tank sampling shows core sampling being completed for all ferrocyanide tanks by the end of FY 1995. Both rotary-mode and push-mode core sampling capabilities are available for obtaining core samples from the Watch List tanks. Tanks without saltcake and with relatively soft waste solids can be core sampled by the push-mode method. If a hard saltcake layer is present, rotary-mode core sampling will be used. The first ferrocyanide tank scheduled for rotary-mode core sampling is 241-BY-104 in May 1994. Push-mode core sampling of tanks 241-C-111 and -C-108 are scheduled in April 1994.

Each core consists of several 48-cm (19-in.) segments (or portions thereof) depending on the depth of the waste in the tank. The sludge layer in these cores will be divided into four 12-cm (4.75-in.) subsegments for each 48-cm (19-in.) segment. If the tank contains a saltcake layer, the saltcake segments will be divided into only two subsegments. Process flowsheet knowledge, tank historical data, and results obtained from tests with ferrocyanide sludge simulants are used to supplement the analytical results from core sampling. 
The priority for sampling ferrocyanide tanks has been changed to reflect the need to determine the reactive properties of the contents. In response to DNFSB Recommendation 93-5 (DOE 1994) to expedite sampling and analyses required to address safety issues in the Hanford Site Watch List tanks, the analysis plans for future ferrocyanide tank core samples (and the plans for other Watch List tanks) have been revised. The Watch List tanks have been given priority for core sampling, and the number of required analytes was reduced and refocused on safety-related properties.

- Protres During Reporting Perfod. The Data Quality Objective (DQO) report released during the last reporting period provides requirements for data used to make safety decisions (Buck et al. 1993). The ferrocyanide data quality objectives are now being applied to the analytical laboratory data obtained for tank 241-T-107. All sampling requirements outlined in the DQO document assume a representative core is available. If core recovery is poor, results may be biased.

Sample recovery for tank 241-T-107 was only sufficient to split three of the 12 core segments into half segments. The core segments split were: core 51-segment 3; core 51-segment 4; and core 52-segment 3. A summary of this limited data is presented in Table 4-1. Noticeable trends can be observed by correlating the data according to the DQO requirements. The middle and lower depths of sludge are about $55 \mathrm{wt} \%$ water. The concentrations of sulfur and strontium increase from the middle to lower depths, but then noticeably drop at the deepest layer of waste.

Table 4-1. Spacial Examination of Data Obtained from Tank 241-T-107.

\begin{tabular}{|l|c|c|c|c|}
\hline $\begin{array}{c}\text { Core No.- } \\
\text { Segment No. }\end{array}$ & $\begin{array}{c}\mathrm{CN}^{-} \\
(\mu \mathrm{g} / \mathrm{g})\end{array}$ & $\begin{array}{c}{ }^{50} \mathrm{Sr} \\
(\mu \mathrm{Ci} / \mathrm{g})\end{array}$ & $\begin{array}{c}{ }^{137} \mathrm{Cs} \\
(\mu \mathrm{Ci} / \mathrm{g})\end{array}$ & $\begin{array}{c}\mathrm{S} \\
(\mu \mathrm{g} / \mathrm{g})\end{array}$ \\
\hline $51-3$ (top) & 109 & 190 & 15.3 & 3,440 \\
\hline $51-3$ (bottom) & 102 & 240 & 17.1 & 4,270 \\
\hline $52-3$ (top) & 54 & 99 & 7.8 & 2,630 \\
\hline $52-3$ (bottom) & 46 & 16 & 10.6 & 3,530 \\
\hline $51-4$ (top) & 89 & 232 & 17.9 & 4,370 \\
\hline $51-4$ (bottom) & 57 & 28 & 13.6 & 3,080 \\
\hline
\end{tabular}


The original February 28, 1994 milestone for completion of the 241-T-107 data interpretation report was deferred to August 15, 1994. Completion of the report is being delayed by the lack of available data because of poor core recovery. Although core recovery was poor, extremely low energetics and cyanide values obtained from the samples that were collected suggest that waste from tank 241-T-107 poses minimal risk for an exothermic ferrocyanide reaction. Therefore, there are no plans to re-sample this tank in the near future.

- Pinnned Work For Subsequent Months. The data interpretation report for tank 241-T-107 will be completed in August 1994. The ferrocyanide DQO document (Buck et al. 1993) will be updated and re-released next quarter as a Weatinghouse Hanford Company Supporting Document (SD). Because the DQO report is a living document and may receive several revisions, the SD format allows the Hanford laboratories to quickly retrieve the most current version for their use.

- Problem Areas and Actions Taken. None.

- Millostone Status.

- February 28, 1994: Complete interpretation of ferrocyanide tank 241-T-107 analytical data and issue a report cleared for public release. This milestone was deferred to August 15, 1994, because of difficulty in interpreting the limited data from core samples with low recovery.

- September 30, 1994: Obtain full-length push-mode core samples from two ferrocyanide tanks (241-C-111 and -C-108).

- September 30, 1994: Obtain full-length rotary-mode core samples from three ferrocyanide tanks (241-BY-104, -106, and -105).

- September 30, 1995: Obtain full-length rotary-mode core samples from the remaining ferrocyanide tanks.

- March 31, 1995: Complete data interpretation reports, for public release, for five ferrocyanide tanks (241-C-111, -C-108, 241-BY-104, -BY-106, -BY-105).

- June 28, 1996: Complete data interpretation reports, available for public release, for the remaining ferrocyanide tanks.

Fourier Transform Infrared Spectroscopy Analyses. FTIR spectroscopy is rapidly becoming the method of choice for demanding applications such as in situ and remote characterization of highly toxic and hazardous materials. Recent developments in FTIR- 
based fiber optic spectroscopy have provided a new methodology to chemically characterize ferrocyanide-bearing waste. Chemometrics and microprocessors that allow storage and rapid analyses of data have significantly contributed to the development of state-of-the-art fiber optic probes.

- Progres During Reporting Period. A preliminary study (Rebagay et al. 1994) was conducted to determine the potential of a remote FTIR system and to assess possible limitations. Experiments were conducted on In Farm ferrocyanide simulant. The technique is based on fiber optic evanescent field absorption with the optical fiber serving as an all-fiber absorption cell. Silver halide (AgBr/Cl) and very low-OH sillica fibers were used as waveguides for mid-infrared and near-infrared radiations, respectively. In general, the spectra obtained resembled those collected from the same waste using conventional FTIR sampling accessories (Rebagay et al. 1993). This study demonstrated the potential application of the technique for hot cell deployment. Work is underway to develop a chemometric quantitation method to analyze spectral data. Concurrently, commercial fiber optic probes optimized for Hanford Site waste characterization have been ordered.

An alternative to the fiber optic option, suitable for the characterization of milligram quantities of actual waste, is the use of hollow light guides. A system of robust metallic optical conduits can provide the infrared transmission capability to communicate between the FTIR spectrometer and the sample located in a laboratory hood up to 30 feet away. Such a setup isolates the sample from the spectrometer, prevents potential radioactive contamination of the spectrometer, and also minimizes personnel radiation exposure. Preliminary examination of the data indicates that this technique can measure ferrocyanide and water simultaneously in the mid-infrared region.

Fourler Transform infrared-photoacoustic (FTIR-PAS) spectroscopy is one of the instrumental methods used to study the molecular structure of a variety of materials. This technique's ability to characterize waste sludges is being investigated by Ames Laboratory of Iowa State University in collaboration with Westinghouse Hanford Company. Preliminary results show it to be a useful complementary technique to the fiber optic and light guide techniques being developed at Hanford.

There is much interest in knowing specific locations, concentrations, and chemical structures of ferrocyanide waste. Infrared microspectroscopy can be a suitable method for addressing this interest. With an infrared microscope, equipped with a computer-controlled micropositioning stage as a micro-sampling accessory, infrared spectral information can be obtained at precise spatial locations. Well-defined areas as small as 10 micrometers $(\mu \mathrm{m})$ in diameter can be probed. A new FTIR spectrometry system equipped with a near-infrared Raman and infrared microscope accessories has been purchased and installed at 
Westinghouse Hanford Company. This instrument is capable of microspectroscopic imaging for compositional mapping of the ferrocyanide waste. Additionally, the waste can be screened for its molecular structure both by infrared and Raman methods using the same instrument.

- Planned Work For Subsequent Months. In the next quarter, Ames Laboratory is scheduled to transfer to Westinghouse Hanford Company part of the FTIR-PAS technology it has developed for waste sludge characterization.

Visible and infrared light examinations of the ferrocyanide sludge will be conducted in FY 1994.

- Problem Areas and Actions Taken. None.

- Milestone Status.

- July 30, 1994: Provide an interim letter report on the status of FTIR system performance in analyzing simulants and actual waste material.

- September 30, 1994: Issue a publicly available progress report on FY 1994 FTIR work with recommendations on future work.

- September 30, 1995: Issue a final report on FTIR technology development and demonstration, if warranted.

- September 30, 1996: Deploy an in situ FTIR system, if warranted.

\subsubsection{Estimation of Moisture Content}

Methods for determining moisture concentrations in ferrocyanide waste tanks are being developed using data analysis and available surveillance systems. Two in situ moisture monitoring technologies are currently being investigated by the Ferrocyanide Safety Program: neutron diffusion and near infrared (NIR) spectroscopy. Additional moisture monitoring technologies, such as copper foil activation, phase change thermal measurements, electrical conductivity, and time domain reflectometry, are being evaluated by other programs.

Neutron Dirrusion. Well-logging techniques, coupled with computer modeling, are being developed and applied to an existing neutron probe to determine information about moisture levels, material interfaces, and other waste characteristics in the ferrocyanide tanks. The development of a new, improved neutron diffusion based detector system is being investigated. This improved technique would primarily be used to determine the axial moisture concentration profile within the ferrocyanide tanks. 
Moisture measurement using neutron diffusion is an established technology. The technique uses a neutron source and one or more neutron detectors. The thermal neutrons reaching a detector originate as fast neutrons from the source and are slowed or absorbed by the medium. Because hydrogen atoms are effective at slowing down neutrons, the detector response is a strong function of the surrounding moisture concentration.

Two methods are generally used in the measurement of moisture concentration around wells using neutron diffusion. The first method, the moisture gauge, has a short source-to-detector spacing on the order of 0 (the source is placed in a ring around the detector) to $6 \mathrm{~cm}$. The response of a moisture gauge is characterized by an increase in detector response with increasing moisture concentration of the surrounding medium. The second method, the neutron $\log$, often has two detectors with longer source-to-detector spacings $(20$ to $50 \mathrm{~cm})$. The detectors in a neutron $\log$ arrangement exhibit a decreased response to increased moisture concentrations. The detector placed at the shorter spacing is used to correct the response of the longer-spaced detector for borehole effects.

The source-to-detector spacing of the existing probe may be adjusted with the addition of a source extender. Computer modeling of the existing neutron probe system revealed that, in its current configuration, it responds most like a moisture gauge. The probe will operate as a neutron $\log$ with the addition of a source extender.

- Progress During Reporting Period. Using the knowledge gained from computer modeling, in situ measurements, and experimental calibration data with the current in-tank neutron probe (Watson 1993), prototype moisture measurement neutron probes have been designed. The probes are being assembled and tested. These prototype devices will utilize both thermal and epithermal neutron detectors, and will allow for both shorter and longer source-to-detector spacings than the current in-tank probe. To evaluate the prototype probes, a test area has been established. The probes will be calibrated in ferrocyanide waste simulants and will be tested in gamma fields comparable to those expected in the ferrocyanide waste tanks.

Neutron detectors for the prototype probes were obtained and initial tests using a Cf-252 neutron source were performed this quarter. The resolution and optimum operating voltages were determined for the probes. High-voltage power supplies, preamplifier circuitry, lead gamma shields, and thermal neutron shields were obtained for initial testing of the probes. A test housing to hold the neutron source and a saltcake simulant-filled drum, containing about $17 \mathrm{wt} \%$ moisture, were fabricated this quarter.

A modeling study was completed to determine the potential effects of transuranics on neutron moisture measurements. Results indicated that mc'sture measurement would be unaffected by the low concentrations (about $10^{-3} \mathrm{~g} / \mathrm{L}{ }^{239} \mathrm{Pu}$ ) expected in most ferrocyanide tanks. For conceritrations of less than about $1 \mathrm{~g} / \mathrm{L}{ }^{239} \mathrm{Pu}$, the increase in the background neutron flux could be 
easily measured during a passive neutron scan of the tank. Subsequent active moisture measurement neutron scans can be corrected for this value. For concentrations of more than about $1 \mathrm{~g} / \mathrm{L}^{239} \mathrm{Pu}$, both the passive neutron counting rate and the rate observed with a neutron source attached to the probe would quickly increase. Such an effect could be readily measured and identified, but would make an accurate interpretation of neutron data for moisture estimation difficult.

Previous modeling and experimental measurements have shown that a neutron probe can measure moisture concentrations of surrounding homogeneous moisture content materials. In-tank photographs and neutron scans have shown that the actual material geometry surrounding the LOW is sometimes more complicated. Annular air holes exist around some LOWs and other material anomalies could exist immediately around a LOW. Material anomaly studies have included modeling and visualization of the interrogation volume of the probe as it scans through material interfaces surrounding a LOW. Figure 4-1 shows a cross-sectional view of the gametry, materials, and calculated neutron interaction densities modeled to represent tank 241-BY-111. The shading surrounding the detector represent the location and density of neutron scattering events for neutrons that are eventually detected in the detector.

These studies are leading to an increased understanding of scans obtained from several ferrocyanide tanks: Modeling suggests that it should be possible to identify many of the anticipated anomalies (e.g., air-filled rings, liquid-filled rings, dry waste rings, and liquid-saturated waste rings) and make appropriate corrections to the moisture estimate.

- Planned Work for Subsequent Months. Final tests will be performed on the completed neutron probe prototypes. These tests will include moisture response calibrations with known moisture content ferrocyanide waste simulants, and tests under gamma irradiation. Computer modeling will be performed to compare calculated predictions with the measurements. These same computer models will then be adapted to perform tank waste modeling. Results of the tank waste modeling will assist with interpretations of prototype tank scans yet to be performed. Initial test scans of ferrocyanide tanks using the prototype probes are scheduled to begin in June 1994.

- Problem Areas and Action Taken. Simulants, neutronically equivalent to ferrocyanide waste, with known moisture (hydrogen) concentrations must be acquired for final testing and calibration. In order to correct for material inhomogeneities around the LOW, experimental results will be needed in simulants arranged to model anticipated material geometries. These results will be used to confirm modeling results for a few selected physical situations and moisture contents. Simulant compounds, with neutronic properties matched to 
Figure 4-1. Cross-Sectional View of the Geometry, Materials, and Calculated Neutron Interaction Densities Modeled to Represent Tank 241-BY-111.

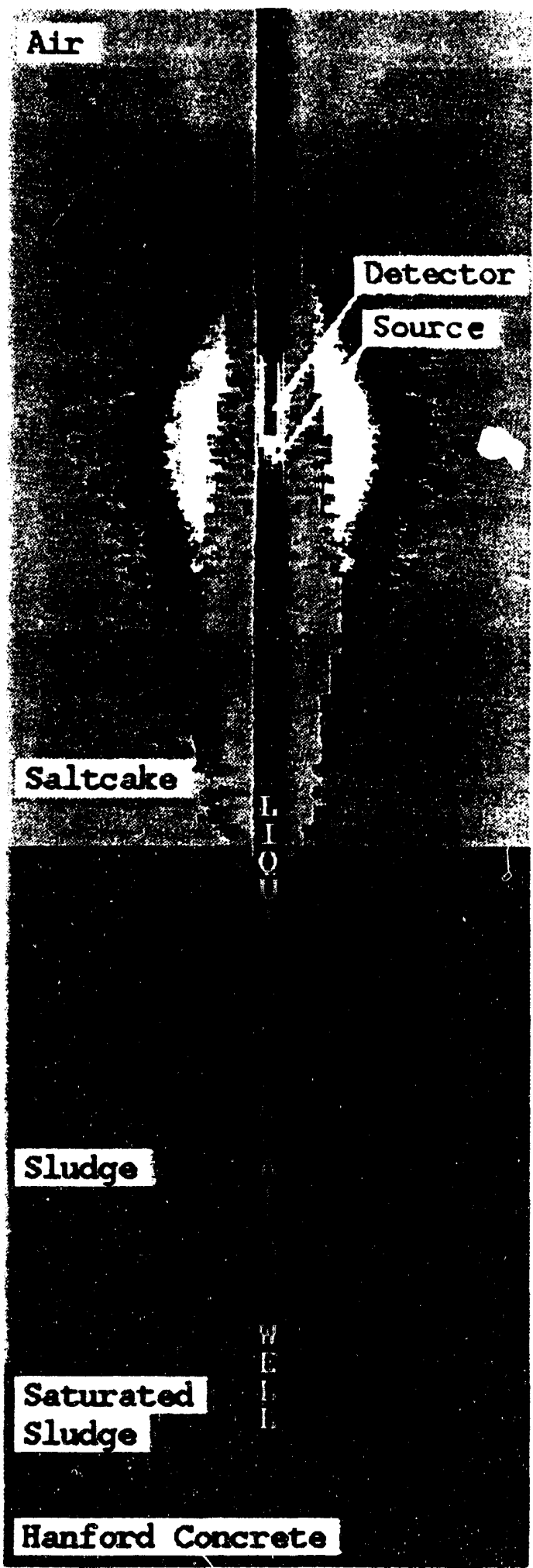


those expected in actual tank waste, have been identified. These simulant formulations will be prepared to evaluate the prototype probes. Unexplained measured neutron probe count rates at the bottom of some tank LOWs have been observed. Further investigation revealed that the most probable cause of these observed count rates is the presence of several inches of water condensed in the bottom of the LOW.

- Milestone Status.

- September 30, 1994: Provide a documented working prototype neutron probe system for moisture monitoring.

- September 30, 1995: Complete installation and deployment of the first phase of the neutron moisture monitoring system and initiate monitoring.

- September 30, 1996: Complete installation and deployment of the neutron moisture monitoring system for routine monitoring in ferrocyanide tanks.

Near Infrared Spectroscopy. Infrared spectroscopy of samples containing water is normally dominated by strong absorption from the water molecules. The strength of this absorption is sufficient that the back scattered light from a surface can be used to determine the water content. In this application, the near infrared $1.4-1: 5 \times 10^{-6}-\mathrm{m}$ region is being investigated for moisture determination in tank waste materials. This optical band, in addition to having a strong sensitivity to water, can be instrumented with conventional optical fibers, windows, and lens components.

For waste tank applications, two methods of implementing NIR absorption are being investigated. Both approaches use back-scattered NIR energy and wavelength processing to extract moisture data. The first method uses an NIR spectroscopy system with a remote fiber optic probe that makes a point moisture measurement. This system could be deployed by a cone penetrometer or surface scanning arm, such as the light duty utility arm being developed for early in situ tank investigations. Deployment as a contact or non-contact sensor is possible since window and lens components are available for the NIR optical region. The second implementation method being investigated is a non-contact remote camera with a sensitive NIR detector and powerful NIR source that will measure moisture of a point from a large lift-off distance. By scanning this point over the waste surface, moisture data can be obtained, in much the same way that temperature contours are obtained using thermal cameras.

- Progress During Reporting Period. The University of Washington's Center for Process Analytical Chemistry (CPAC) is completing a Phase 2 study addressing issues such as particulate size and material matrix changes. A previous Phase 1 CPAC task revealed that for three spectral regions (visible, NIR, and mid-infrared) the NIR region produced the best moisture sensitivity $(0.5 \mathrm{wt} \%$ 
limit over a 0 to $20 \mathrm{wt} \%$ moisture range) and the simplest (one parameter) calibration model. A Phase 2 full-scale demonstration completed by CPAC has shown that there is adequate sensitivity to consider a non-contact camera type moisture sensing system.

A Phase 3 task was contracted to CPAC this quarter to complete the tank-scale test/demonstration, to optimize and transfer the NIR calibration technology to Westinghouse Hanford Company, and to provide calibration standards for T Plant and tank 241-BY-104 saltcake simulants. CPAC will also test the NIR concept with the T Plant and 241-BY-104 saltcake simulants.

Cold testing was initiated with the NIR spectroscopy system delivered by Savannah River Laboratory (SRL). An initial system documentation (system operating document) task was necessary, since the system came from SRL without documentation. The cold test will be used to evaluate the performance of the NIR system prior to moving it into a hot cell environment. The CPAC NIR calibration model will be integrated with this NIR spectroscopy system to develop a complete remote probe moisture sensing system.

A list of archived tank waste materials has been identified and will be used for hot cell moisture testing. The hot cell, resources, and archived tank materials in the 222-S Hot Cell Laboratory will be used for this work. Efforts to obtain a second NIR system for hot cell use are underway and the second system should be operational by September 1994 .

- Planned Work for Subsequent Months. Operational documentation for the SRL system will be completed to support cold and hot cell system operation. To accelerate this work, a second NIR system is being acquired from SRL that will be used for hot cell testing. Integration of an SRL NIR system with the CPAC calibration model will be initiated and a report on CPAC Phase 2 moisture sensing feasibility work will be published.

- Problem Areas and Action Taken. None

- Milestone Status.

- March 31, 1994: Complete the Phase 2 surface monitoring interference study/scale up report. Transmittal of the report from CPAC has been delayed approximately four weeks.

- August 31, 1994: Complete Phase 3 surface monitoring work and provide a report.

- September 30, 1995: Complete the surface moisture measuring development work and the in-tank demonstration test. 
- September 30, 1996: Initiate installation of surface moisture monitoring equipment if the demonstration test is successful and the need is warranted.

- September 30, 1997: Complete installation of the surface moisture monitoring system, if warranted.

\subsubsection{Preparation and Characterization of Ferrocyanide Waste Simulants}

Ferrocyanide waste precipitates are being prepared and analyzed to determine the composition, physical properties, and chemical reaction properties of simulants that represent ferrocyanide waste stored in SSTs. The analytical results from these simulants, along with analyses of actual tank waste samples, waste tank monitoring, and waste modeling, provide information to characterize with a great deal of assurance any safety concerns relating to the sludge in each of the ferrocyanide tanks.

Five waste simulants (without radioactive species) are being used to represent the variety of waste produced in the mid-1950s and stored in SSTs. Ferrocyanide waste produced at the Hanford U Plant is represented by U Plant 1 and U Plant 2 test mixtures. The U Plant 1 waste simulant represents 41 of 59 batches and the U Plant 2 simulant represents 9 of 59 batches of $U$ Plant waste. The average $U$ Plant batch volume was about 2,300,000 L $(600,000 \mathrm{gal})$. The other nine batches of $U$ Plant waste are expected to have a ferrocyanide concentration between that of U Plant 1 and $U$ Plant 2. A test mixture representing these batches will not be prepared and tested.

The In Farm flowsheet waste (in four C Farm tanks) is represented by In Farm 1 and In Farm 2 test mixtures. The In Farm 1 test mixture is representative of one batch (expected to have the greatest ferrocyanide concentration) of the 29 In Farm batches processed in the 1950s. In Farm 2 is representative of 11 intermediate ferrocyanide concentration batches of the 29 In Farm batches. An average-sized In Farm batch was approximately 1,500,000 L $(400,000 \mathrm{gal})$. It should also be noted that 6 of these 29 scavenging batches did not contain any ferrocyanide, but sodium sulfide was added to enhance precipitation of ${ }^{60} \mathrm{Co}$.

A T Plant simulant was prepared for testing to represent the six $\mathrm{T}$ Plant batches produced. An average sized T Plant batch was 2,098,000 L (554,000 gal). The T Plant ferrocyanide sludge is stored in three TY Farm tanks.

Three main adjustments from the actual processes used in the 1950 s were made in the laboratory scavenging preparation method to provide waste simulants representative of ferrocyanide sludges. These changes are as follows: (1) the solution concentrations were adjusted to include nitrite at a 1:3 mole ratio of nitrite/nitrate, to account for nitrite buildup over time in the waste by radiolysis of nitrate; (2) the waste simulants prepared for characterization do not contain radioactive isotopes present in actual waste, because of the difficulty in working with radioactive materials; and (3) the settled waste simulants from the 
laboratory scavenging process were centrifuged at a force of $\sim 2,500$ gravities to mimic an equivalent 30-year settling period.

The moisture content of ferrocyanide sludge is very important in the exothermic reaction behavior of ferrocyanide/nitrate-nitrite mixtures. Studies are underway to evaluate the moisture retention properties of ferrocyanide simulants as they relate to possible waste tank leaks, tank stabilization by pumping, and possible evaporation from exposed surfaces.

- Progress During Reporting Period. Tests are continuing to determine the amount of moisture remaining in the simulants in the event of a free-flowing drainage, such as a tank leak or saltwell pumping of liquids for tank stabilization. Three types of tests are being conducted: (1) a free flowing liquid drainage test using In Farm 2 top fraction simulant at one atmosphere pressure; (2) centrifuge tests with open ended drainage up to 2000 gravities; and (3) gas pressure tests in Tempe ${ }^{3}$ cells.

The free-flowing liquid drainage test has continued 21 months. A 4-inch diameter column was filled to a height of 8 inches with In Farm simulant and allowed to gravity drain. The initial free water content of the simulant was $53 \mathrm{wt} \%$. Calculations from the measured liquid drained to date indicate that the remaining material has a water content of about $49 \mathrm{wt} \%$ (Figure 4-2). Liquid is continuing to drain very slowly from this material with no termination anticipated in the near future. Some consolidation of this simulant has been observed during the test.

Figure 4-2. Weight Percent of Free Water Remaining as a Function of Time.

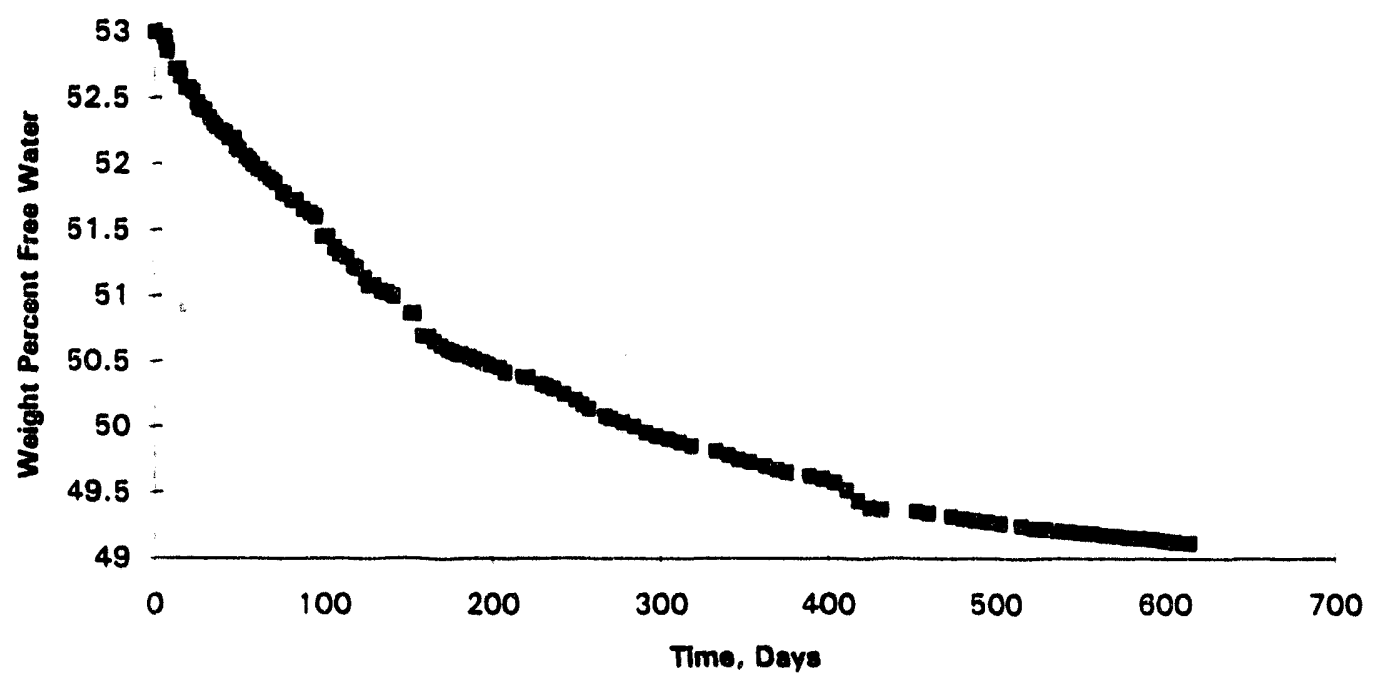

${ }^{3}$ Trademark of Soil Moisture Equipment Corporation, Santa Barbara, California. 
Scoping, vented centrifugation tests conducted at 10,20,50,100, and 2000 gravities with In Farm simulant on a fritted porus media (30- $\mu \mathrm{m}$-sized openings) resulted in final water contents of about $48,47,46,45$, and 34 wt\%, respectively. This identifies a final water content which is above the minimum water required to prevent propagation in the most concentrated ferrocyanide simulant. Consolidation was measured for these tests and indicates that the decrease in simulant volume corresponded closely to liquid volume loss. This suggests that liquid loss from the simulant is due to consolidation rather than unsaturated flow of liquid from the simulant. The decrease in volume was only slightly greater than the volume of liquid lost from the samples. Permeability calculations are being evaluated from these test results.

Modeling analysis of simulant drainage is continuing to evaluate ferrocyanide sludge water loss during gravity drainage. Data from the small column, centrifugation experiments, and Tempe ${ }^{\mathrm{TM}}$ cell tests are being used to estimate the hydraulic properties that control liquid flow in the sludge. The modeling will incorporate consolidation processes observed during the various tests. Potential evaporative loss of water from the waste is being evaluated to determine if the modeling should include this phenomenon also. Sludge has been shown to lose moisture under low relative humidities.

- Planned Work for Subsequent Months. A ferrocyanide waste simulant based on characterization of actual tank waste samples will be prepared, analyzed, and tested. Propagation tests will be conducted to determine the minimum water content which will prevent a stoichiometric mixture of ferrocyanide and nitrate/nitrite from propagating when exposed to a strong ignition source. Simulant drainage and centrifugation tests will continue. The effects of relative humidity on moisture content will be evaluated under geometric conditions representative of the SSTs.

A report on the three methods used for drying the ferrocyanide waste simulants will be prepared and issued.

- Problem Areas and Actions Taken. None.

- Milestone Status.

- March 31, 1994: Issue a report, available to the public, on the evaluation of the three waste simulant drying methods. Because of data interpretation difficulties, a decision was made to repeat some of the moisture analyses. Therefore, publication of this report will be delayed approximately two months.

- May 31, 1994: Issue a report, available to the public, on the chemical and physical properties of the T Plant ferrocyanice waste simulant. 
- September 30, 1994: Complete drainage tests on ferrocyanide waste simulants and issue a publicly available report on modeling and moisture retention by ferrocyanide sludge.

- September 30, 1994: Issue a publicly available report on the effects of relative humidity on moisture retention in ferrocyanide waste.

\subsection{CHEMICAL REACTION STUDIES}

"The schedule for the program on study of the chemical properties and explosive behavior of the waste in these tanks is indefinite and does not reflect the urgent need for a comprehensive and definitive assessment of the probability of a violent chemical reaction. The study should be extended to other metallic compounds of ferrocyanide that are known or believed to be present in the tanks, so that conclusions can be generalized as to the range of temperature and other properties needed for a rapid chemical reaction with sodium nitrate."

Chemical reaction studies on ferrocyanide waste simulants are being conducted by Westinghouse Hanford Company, Fauske and Associates, Inc. (FAI), PNL, and Los Alamos National Laboratory. Westinghouse Hanford Company and PNL have produced flowsheet simulant materials for testing and characterization. FAI is conducting adiabatic calorimetry and propagation tests on these same flowsheet materials.

\subsubsection{Chemical Reaction Studies at Pacific Northwest Laboratory}

Chemical reaction studies are continuing at PNL using flowsheet simulant materials. Waste studies addressing DNFSB Recommendation 90-7.5 were conducted to determine: (1) aging effects of more than 35 years of storage in the tanks; (2) the speciation of cyanides found in the actual tank waste; (3) the solubility of sodium and cesium nickel ferrocyanides; and (4) possible microconvection mechanisms that may have allowed mixing of the ferrocyanide sludge with caustic solutions added to the tanks during tank operations.

- Progress During Reporting Perlod.

Aging Studies. Additional work was performed during the quarter to determine the influence of soluble cesium ion on the dissolution of ferrocyanide waste simulants. Two experiments were conducted to explore the dissolution of vendor material $\left[\mathrm{Na}_{2} \mathrm{NiFe}(\mathrm{CN})_{6} \bullet \mathrm{Na}_{2} \mathrm{SO}_{4} \bullet 4.5 \mathrm{H}_{2} \mathrm{O}\right]$ in caustic solutions (3M and $4 M$ $\mathrm{NaOH}$ ) containing $2.3 \times 10^{-3} \mathrm{M} \mathrm{CsNO}_{3}$. Results from both experiments were very similar. Dissolution, as determined by the soluble iron in solution (ferrocyanide anion), was 70 to $80 \%$ complete within two minutes, and reached 85 to $90 \%$ after 24 hours. Cesium uptake was also very rapid, with $98 \%$ incorporation into the solid phase after two minutes. Figure 4-3 compares results of additional experiments which were conducted in $4 M \mathrm{NaOH}$ with $3 \times 10^{4}$ and 
$2.3 \times 10^{-3} M$ cesium ion. About $10 \%$ less dissolution was observed at the higher cesium concentration.

The dissolution behavior of the vendor material in the presence of soluble cesium is much different from that of the In Farm 1 material that already contains cesium in the solid phase. Cesium in the solid phase inhibits dissolution, making dissolution of the In Farm 1 material slow relative to material not containing cesium. Dissolution of the vendor material is not inhibited initially and dissolution is rapid. However, as cesium exchanges into the solid phase, dissolution slows and eventually stops.

Figure 4-3. Dissolution of Vendor Material in $4 M \mathrm{NaOH}$ in the Presence of $3 \times 10^{-3}$ and $3 \times 10^{-4} M$ Cs Ion

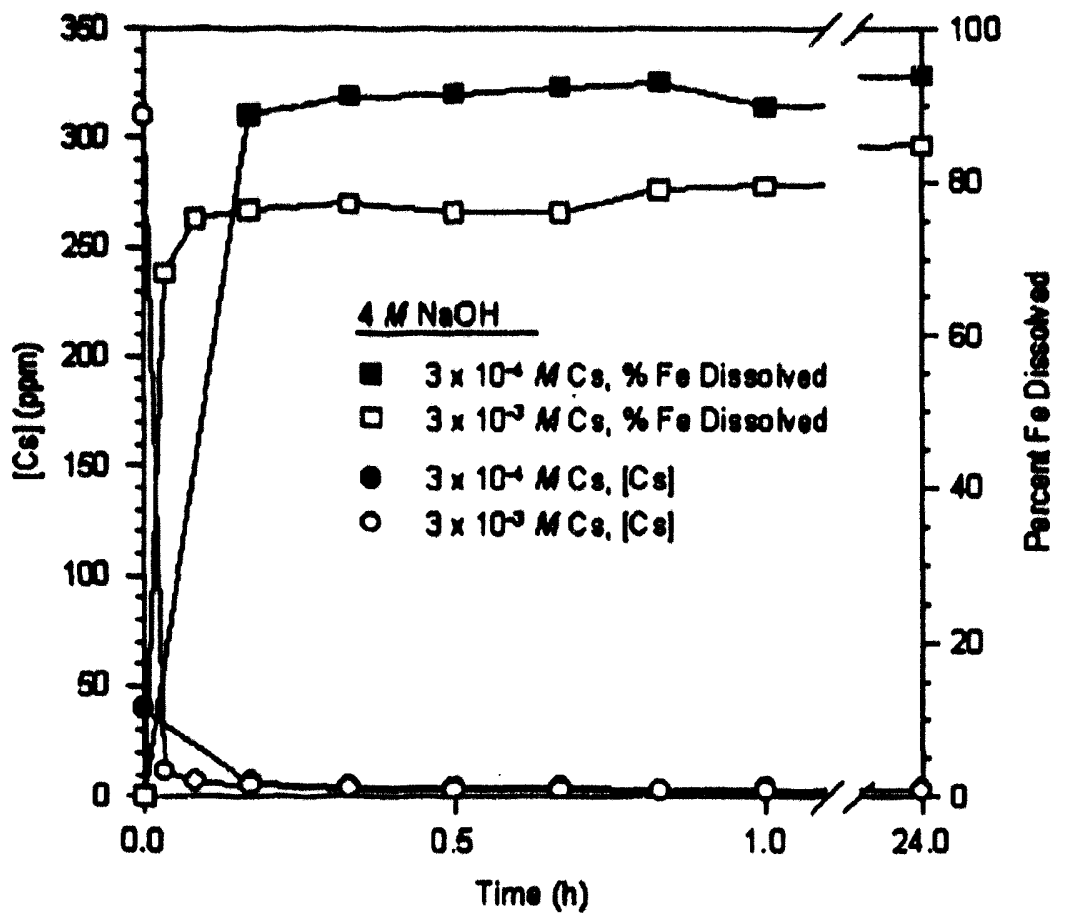

Two aging experiments were completed in the gamm.a pit this quarter. Both experiments were conducted using 0.5 grams of In Farm 1 simulant in $25 \mathrm{~mL}$ of $2 M \mathrm{NaOH}$. The samples were irradiated at $1 \times 10^{5} \mathrm{Rad} / \mathrm{h}$ in the gamma pit for three weeks. One experiment was heated to $90^{\circ} \mathrm{C}\left(194^{\circ} \mathrm{F}\right)$ and the other to $70^{\circ} \mathrm{C}\left(158{ }^{\circ} \mathrm{F}\right)$. The vessels were removed from the gamma pit at various times and the contents analyzed for ammonia concentration. Results for the aging experiments are shown in Figures 4-4 and 4-5. The control experiment did not receive gamma irradiation. 
WHC-EP-0474-12

Figure 4-4. Ammonia Production During the Irradiation of In Farm 1 Simulant at $90^{\circ} \mathrm{C}$ in $2 \mathrm{M} \mathrm{NaOH}$

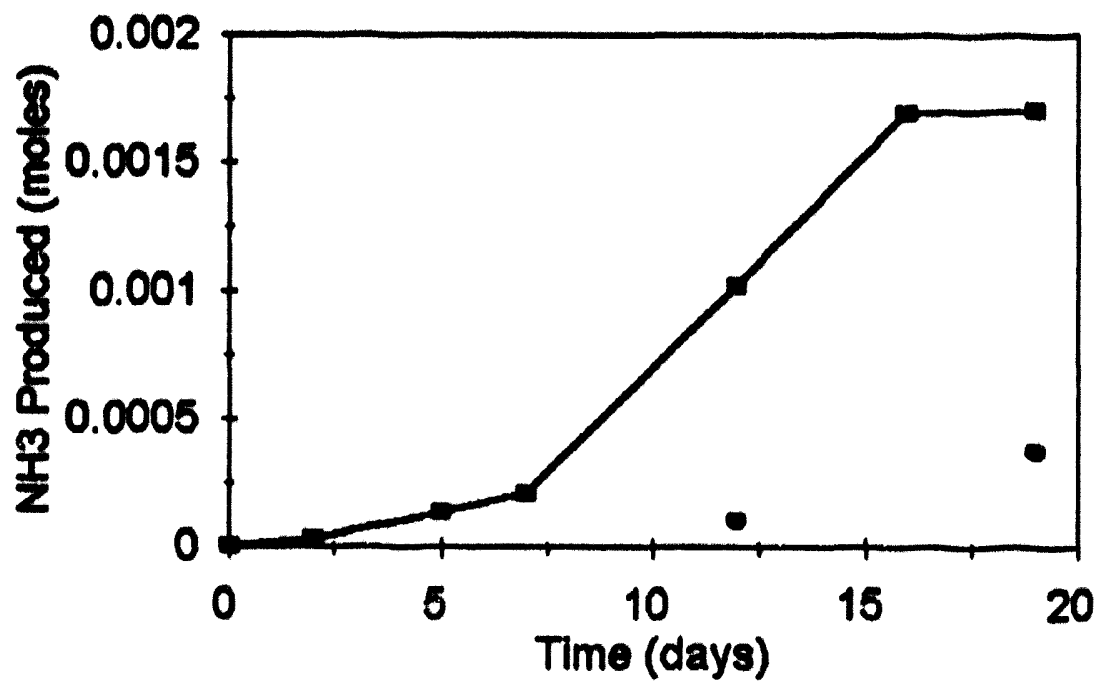

- Gainma - Control

Figure 4-5. Comparison of Ammonia Production at 70 and $90{ }^{\circ} \mathrm{C}$ During Irradiation of In Farm 1 Simulant in $2 M \mathrm{NaOH}$

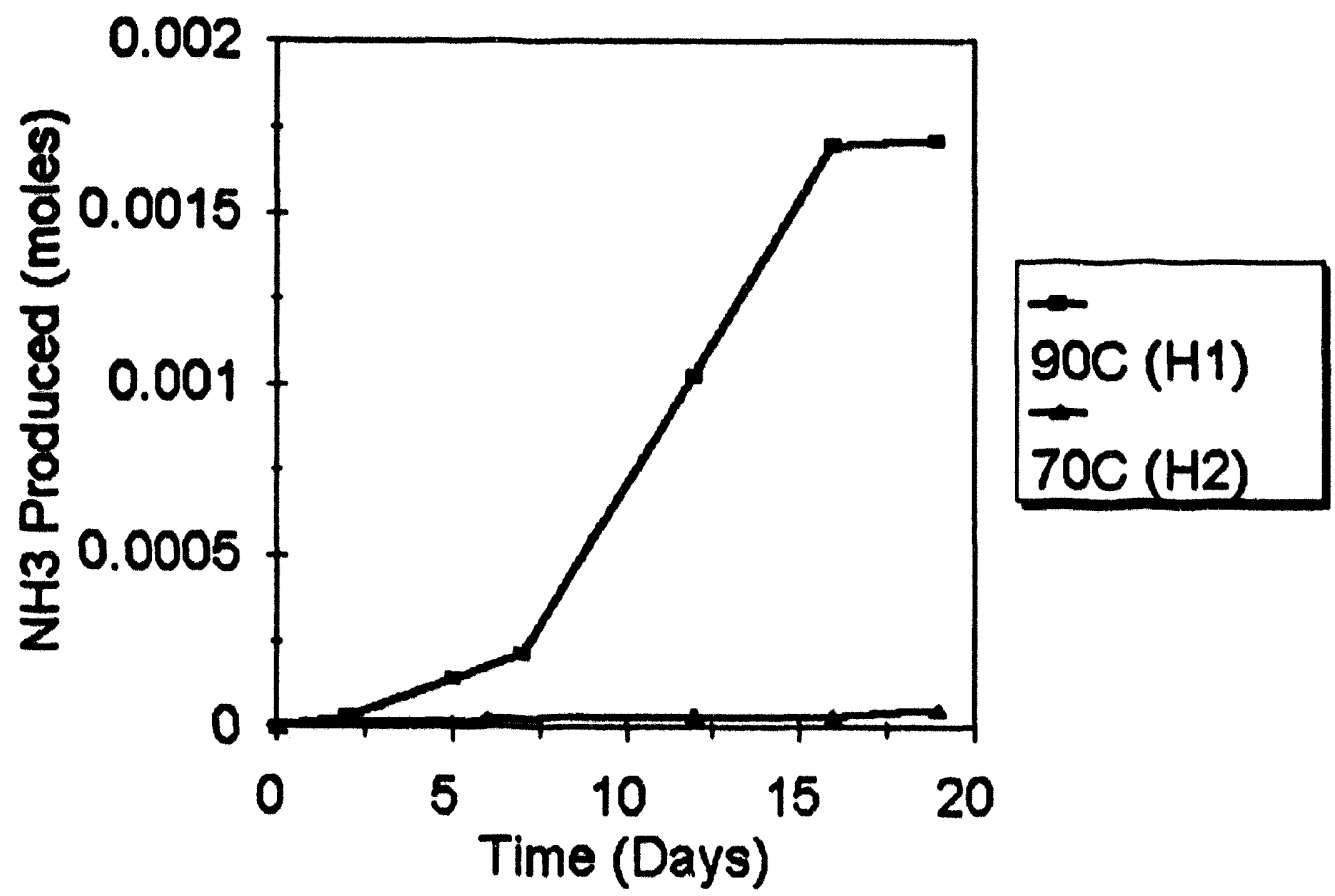


Eramining Figure 4-4, the greater amount of ammonia in the gamma-irradiated veseel shows that gamma radiation promotes hydrolysis. The low ammonia production at the start of the experiment may indicate an induction period or a progressive saturation of the stainless steel surface with ammonia. The amount of ammonia present in the final sample corresponds to approximately $60 \%$ hydrolysis. As shown in Figure 4-5, the extent of hydrolysis was much less at $70^{\circ} \mathrm{C}$. Results for both experiments are plotted on a common abscissa.

Cyanide Specintion. An FTIR spectrometer equipped with a remote detector was installed into a radiologically controlled laboratory this quarter. The spectrometer is equipped with a remote detector compartment located within a rediologically controlled hood for the analysis of radioactive samples. Ferrocyanide tank waste samples from tanks $241-\mathrm{C}-109$ and -112 are being prepared for analysis. Specific samples will be chosen for FTIR analysis to allow comparison of initial FTIR results with previous total cyanide results.

Development work on the ion chromatography speciation method continued during the quarter. Efforts are centered on enhancing the detection limit while maintaining baseline chromatographic separation between ferricyanide $\left(\mathrm{Fe}^{3+}\right)$ and ferrocyanide $\left(\mathrm{Fe}^{2+}\right)$ species. The influence of potential organic and inorganic interferences on cyanide species detection is also being determined. Baseline separation for a combined sample of ferricyanide and ferrocyanide complexes was achieved with each species within the 1-10 ppm concentration range. A low detection limit is important for two reasons. It provides maximum sensitivity for cyanoferrate species present in actual waste samples, and it allows higher dilution factors for tank waste samples, minimizing personnel exposures.

Mileroconvection Modeling. The purpose of this task is to evaluate possible mechanisms for cesium nickel ferrocyanide mobilization and transport. The major efforts are to expand the 2-D transport model (developed last fiscal year) to accommodate multiple species, and then couple the transport code with an equilibrium chemistry model. The end goal of the modeling studies is to quantitatively predict the amount of ferrocyanide that could have been solubilized and subsequently removed from the SSTs. These convection mechanisms include buoyancy-aided flow as a result of gradients in temperature and fluid chemical composition.

During the quarter, a solution algorithm was coded and tested for the 2-D continuity and momentum balance equations. The solution technique uses the stream-function vorticity method to eliminate the pressure variable in the momentum equation. The stream function potential equation is solved using a successive over-relaxation method. The new algorithm was added to the Tank Waste Simulator code and the code now has capabilities for solving coupled fluid, heat, and mass transport problems. The internal heat generation in the 
ank was found to establish a bifurcated flow field, as illustrated in Figure 4-6.

Convective mass transport can occur along the flow streamlines.

Figure 4-6. Bifurcated Flow Field in Porous Waste Sludge

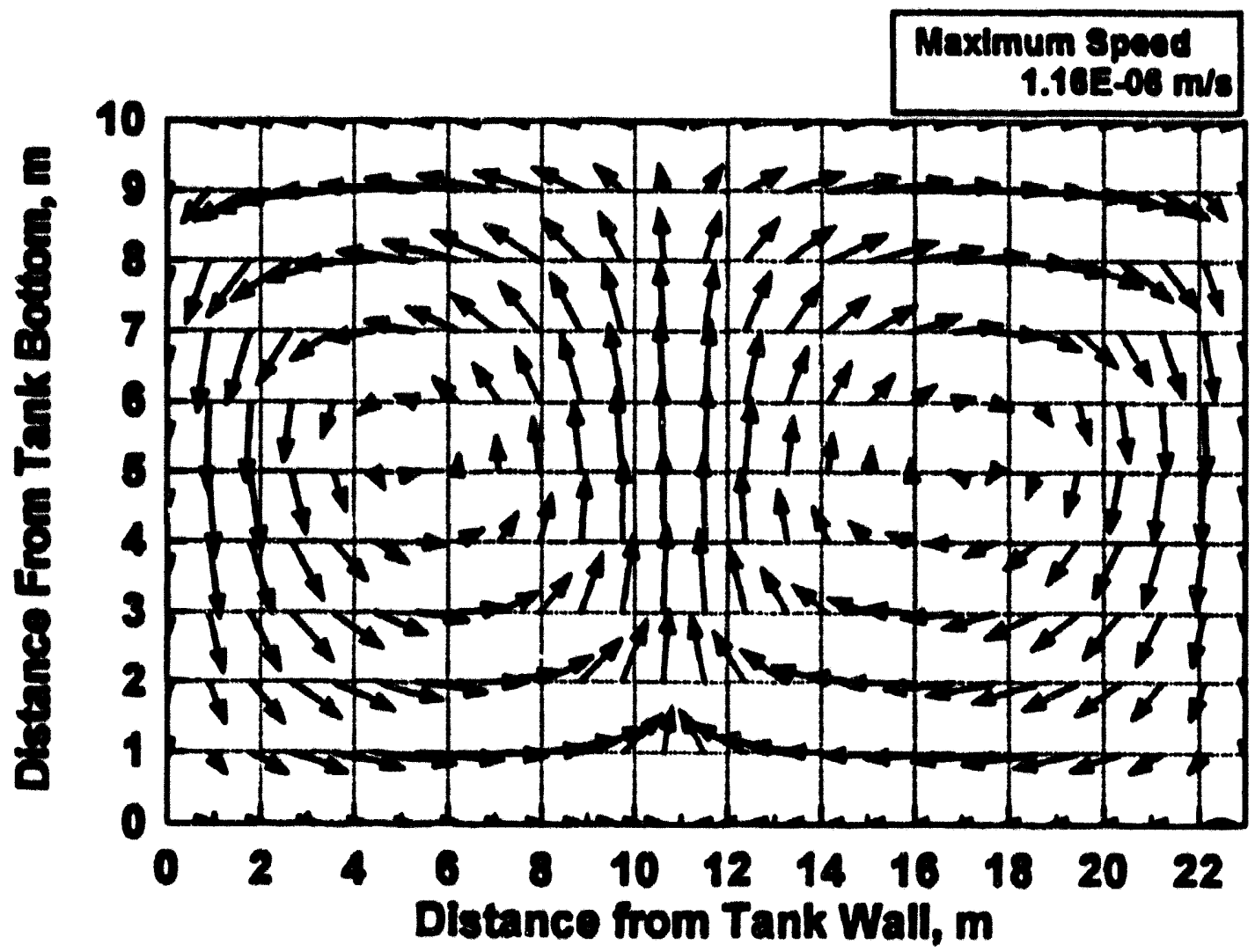

Cyanoferrate Solublilty Study. Solubility studies are being conducted to investigate the solubility of sodium and cesium nickel ferrocyanide compounds. This information will allow accurate prediction of the influence of chemical interactions and physical changes on the concentrations of these materials in the solid and liquid phases of the ferrocyanide tank waste.

Suspensions containing $\mathrm{Ni}_{2} \mathrm{Fe}(\mathrm{CN})_{6}(0.001 \mathrm{M}), \mathrm{CsNO}_{3}(0.00003$ to $1.0 \mathrm{M})$, and $\mathrm{NaNO}_{3}(0.001$ to $10 \mathrm{M})$ were centrifuged and filtered through $0.0018-\mu \mathrm{m}$ filters after mixing for three days. As expected, analyses indicated that $\mathrm{Cs}$ is readily removed from solution by $\mathrm{Ni}_{2} \mathrm{Fe}(\mathrm{CN})_{6}$. With the increasing $\mathrm{Cs}$ concentration, the amount of $\mathrm{Cs}$ removed decreased. The maximum amount of $\mathrm{Cs}$ removed exceeded the amount of Cs required (8.5 milligrams) for the formation of $\mathrm{CsNi}_{1.5} \mathrm{Fe}(\mathrm{CN})_{6}$, as shown in Table 4-2. It is difficult to tell from these results whether the Cs removal is as a result of ion exchange or the formation of a solid 
solution. These aspects will be further investigated in studies that are currently underway.

Table 4-2. Effect of Adding $\mathrm{CsNO}_{3}$ to $20 \mathrm{mg} \mathrm{Ni}_{2} \mathrm{Fe}(\mathrm{CN})_{6}$ Suspensions in $0.001 \mathrm{M}$ NaFe $(\mathrm{CN})_{6}$.

\begin{tabular}{|c|c|c|}
\hline $\begin{array}{c}\text { Initial Cs } \\
(\mathrm{mg} / \mathrm{L})\end{array}$ & $\begin{array}{c}\text { Final Cs } \\
(\mathrm{mg} / \mathrm{L})\end{array}$ & $\begin{array}{c}\text { Cs Removed } \\
(\mathrm{mg})\end{array}$ \\
\hline 3.9 & 0 & 0.16 \\
\hline 13 & 0 & 0.52 \\
\hline 25 & 0 & 1.02 \\
\hline 67 & 0 & 2.68 \\
\hline 136 & 0 & 5.44 \\
\hline 276 & 20 & 9.44 \\
\hline 709 & 478 & 9.20 \\
\hline 2830 & 2302 & 21.1 \\
\hline
\end{tabular}

- Planned Work For Subsequent Months. The aging study radiolysis and hydrolysis experiments will be continued In Farm flowsheet simulant. Temperature and $\mathrm{pH}$ will be evaluated during gamma pit radiolysis experiments to determine rates of hydrolysis under projected tank waste conditions as they existed for the years immediately after ferrocyanide waste scavenging.

Cyanide speciation analytical methods development, including ion chromatography (IC) methods and solution IR methods, will continue until the validated techniques and procedures can be routinely applied to samples in analytical laboratories at PNL and Westinghouse Hanford Company. The studies will include determination of interferences and possible corrections.

Microconvection modeling studies have been expanded and an improved model incorporating key physical and chemical properties will be used to evaluate potential fluid movement in the ferrocyanide tanks.

- Problem Areas and Actions Taken. None 


\section{- Millestone Status.}

- September 30, 1994: Issue the final PNL report, cleared for public release, on FY-1994 hydrolysis and radiolysis aging experiments with ferrocyanide waste materials.

- September 30, 1994: Issue the final PNL report, cleared for public release, on solution IR and IC cyanoferrate speciation activities and application for routine measurements in the analytical laboratories.

- September 30, 1994: Issue a publicly available progress report on FY 1994 work on the solubility of sodium/cesium nickel ferrocyanide compounds, with recommendations on future work.

- September 30, 1994: Issue a PNL report, cleared for public release, on microconvection modeling and the effects projected to have occurred in the tank waste from this phenomenon during more than 35 years of storage.

- September 30, 1994: Issue a progress report, available to the public, on FY 1994 studies comparing chemical and physical parameters of ferrocyanide waste simulants with actual waste samples. The report will include recommendations on future work.

- September 30, 1995: Issue the final PNL report integrating all Ferrocyanide Safety Program hydrolysis and radiolysis aging activities.

- September 30, 1995: Issue a final report, available to the public, on the solubility of sodium-cesium nickel ferrocyanide compounds under waste tank conditions.

- September 30, 1995: Issue a final report, available to the public, on studies comparing chemical and physical parameters of ferrocyanide waste simulants with actual tank waste samples.

\subsubsection{Ferrocyanide Propagation Studies}

Ferrocyanide adiabatic calorimetry and propagation tests are continuing at FAI under contract to Westinghouse Hanford Company. The results of these tests are being used to help determine if local regions within the ferrocyanide waste can ignite and burn to spread and involve additional waste from a potential ignition point. Propagation velocity is a key parameter in determining safety consequences of postulated burns, including a potential radioactivity release. 
Because the composition of the waste in the storage tanks varies and is not known at all locations, ranges of material compositions have been tested. Present work is focused on the $T$ Plant and the more reactive In Farm 1 simulants. Sludge produced by the In Farm flowsheet is stored in four C Farm tanks and represents about $26 \%$ of the total ferrocyanide used in the Hanford Site scavenging processes. Sludge produced by the T Plant flowsheet is stored in three TY Farm tanks and represents about $8 \%$ of the total ferrocyanide used during the Hanford Site scavenging processes. Adiabatic calorimeter tests have also been initiated to assess possible organic fuel contributions to energy releases during ferrocyanide reactions.

- Progress During Reporting Period. Propagation tests were conducted on dried In Farm 1 simulant which was diluted with nitrate to near the limit for propagation. Propagation tests were conducted with dry ( $0 \mathrm{wt} \%$ free water) mixtures at $\mathrm{Na}_{2} \mathrm{NiFe}(\mathrm{CN})_{6}$ concentrations of 12,13 and $14 \mathrm{wt} \%$. Preliminary results of tests at an initial temperature of $30^{\circ} \mathrm{C}\left(86^{\circ} \mathrm{F}\right)$ show that the limit of propagation was between 13 and $14 \mathrm{wt} \%$. The test conducted at $14 \mathrm{wt} \%$ propagated at a very low rate, while the two tests conducted at 12 and 13 wt\% did not propagate. Another test conducted with $13 \mathrm{wt} \% \mathrm{Na}_{2} \mathrm{NiFe}(\mathrm{CN})_{6}$ at an initial temperature of $130^{\circ} \mathrm{C}\left(266^{\circ} \mathrm{F}\right)$ did not propagate.

Preparations are being made to conduct tests with stoichiometric mixtures of disodium mononickel ferrocyanide and nitrate/nitrite to determine the concentration of water which will prevent a propagating reaction for these high fuel concentration mixtures.

- Planned Work for Subsequent Months. Complete propagation screening tests with stoichiometric mixes to identify important parameters. Define additional parametric and ferrocyanide/organic tests to be conducted and initiate these tests at FAI. Conduct dry out tests by simulating local heat generation in the sludge volume.

- Milestone Status.

- July 30, 1993: Complete a report on the T Plant calorimetry and propagation tests and the U Plant dryout tests. This report was completed by FAI on July 28,1993 . The report was publicly released this quarter (Epstein et al. 1994).

- December 15, 1993: Complete a report on conditions necessary for ferrocyanide - nitrate/nitrite propagation. A draft of this report was completed in November 1993 and the report was publicly released this quarter (Fauske and Jeppson 1994).

- June 30, 1994: Complete screening tests of In Farm 1 simulant at FAI by varying ferrocyanide and water compositions to define empirical line that divides propagating and non-propagating mixtures on the triangle diagram 
(Postma et al. 1994). Issue a report, cleared for public distribution, by September 30, 1994.

- March 31, 1995: Complete parametric aerosol tests at FAI (if required) that provide source terms for determining consequences of hypothetical ferrocyanide burns in a ferrocyanide tank.

- September 30, 1995: Complete the ferrocyanide calorimetry and propagation test program at FAI as specified by Westinghouse Hanford Company and prepare reports, available for public release, that support resolution of the Ferrocyanide Safety Issue.

\subsection{EMIERgENCY RESPONSE PLANNING}

"The Boand had recommended 'that an action plan be developed for the measures to be taken to neutralize the conditions that may be signaled by alarms.' Two types of measures are implied: actions to respond to unexpected degradation of a tank or its contents, and actions to be taken if an explosion were to occur. Your implementation plan stated that 'the current contingency plans ... will be reviewed and revised if needed.' We do not consider that this proposed implementation of the Board's recommendation is adequately responsive. It is recommended that a written action plan founded on demonstrated principles be prepared as soon as possible, that would respond to indications of onset of abnormal temperatures or other unusual conditions in a ferrocyanide-bearing tank, to counter any perceived growth in hazand. A separate emergency plan should be formulated and instituted, covering measures that would be taken in event of an explosion or other event leading to an airborne release of radioactive material from the tanks, and that would protect personnel both on and off the Hanford Site. The Boand believes that even though it is considered that the probability is small that such an event will occur, prudence dictates that steps be taken at this time to prepare the means to mitigate the unacceptable results that could ensue."

The Action Plan for Response to Abnormal Conditions in Hanford Radioactive Waste Tanks Containing Ferrocyanide (Cash and Thurman 1991a) was prepared in response to DNFSB Recommendation 90-7.6. The action plan describes the steps to be taken if a temperature increase trend above the tank temperature baseline is measured in any of the ferrocyanide tanks. The document was revised in December 1991 and reissued as WHC-EP-0407, Rev. 1 (Cash and Thurman 1991b) to include the monitoring criteria and responses for abnormal levels of flammable and toxic gases, as well as the reporting requirements, if established criteria are exceeded.

In addition, the Tank Farm Stabilization Plan For Emergency Response (WHC 1991) was issued in March 1991. If a radioactive release from a ferrocyanide tank were to occur, it would be detected by one or more radiation monitoring systems. Significant airborne or ground surface releases that spread beyond the immediate tank or tank farm would be detected by the tank farm area radiation detectors. These monitoring systems are on all tank 
farms. An emergency involving an underground radioactive waste storage tank is a unique event with potentially serious consequences both onsite and offsite. The Stabilization Plan analyzed the potential effects of an event involving one of these tanks, and additional steps were prescribed so that emergency personnel can take mitigating actions in a timely fashion. The Stabilization Plan includes predetermined mitigative actions for terminating the emergency phase and providing a transition to the recovery phase. Acknowledging that an event could range from minor to major releases, the Stabilization Plan addresses responses in four distinct and defined steps that cover a broad range of consequences. The Stabilization Plan provides quick, preplanned actions that can be used to stabilize an emergency event at an underground radioactive waste storage tank.

Emergency event recognition and classification, protective action recommendations, and emergency notification emergency plan implementing procedures for response to tank farm emergencies were completed and issued in June 1992. Training has been conducted and an exercise was completed to validate the effectiveness of the procedures and training.

All actions with respect to emergency planning, emergency event recognition, protective action recommendations, and emergency response procedures have been completed. Further revisions and occasional validation exercises will be accomplished as part of the normal Westinghouse Hanford Company and DOE emergency planning efforts. No further reporting on these issues is planned, and this part of DNFSB Recommendation 90-7.6 is considered complete and closed.

DOE considers this recommendation to be closed with the proviso that the abnormal conditions response plan and emergency plans are: (1) reviewed on a periodic basis; (2) revised and updated as required to incorporate any additional controls determined appropriate by the ongoing Waste Tank Safety Program investigations (e.g., the Action Plan for Response to Abnormal Conditions in Hanford Site Radioactive Waste Tanks Containing Ferrocyanide [Cash and Thurman 1991b] will be updated in May 1994); and (3) validation exercises for various waste tank accident scenarios are conducted (exercises for the tank farms are conducted every two years).

- Progress During Reporting Period. As noted in previous reports, all of the planned milestones for this task were completed.

- Planned Work For Subsequent Months. None planned.

- Problem Areas and Action Taken. None.

- Milestone Status. All milestones have been completed. 


\subsection{PROGRAM SCHEDULES AND MILESTONES}

Two sets of schedules (Figures 5-1 and 5-2) are presented in this section. The scope of some of the program activities has changed since the FY 1992 program plan (Cash and Dukelow 1992) and the revised implementation plan (Borsheim et al. 1992) were released, and progress should be tracked against the schedules presented here. The first set of schedules reviews milestones for FY 1991 through FY 1994; these have been statused through March 31, 1994. A status line was drawn showing the progress completed on each activity. Actions that have started or been completed are indicated by triangles that are filled in. Work indicated by open triangles has either not started or has not been completed. Diamonds indicate a TPA milestone.

The second set of schedules reviews out-year milestones for FY 1994 through the expected end of the program in FY 1997. The sequence and anticipated completion dates of the major milestones leading to Safety Issue resolution are presented. 


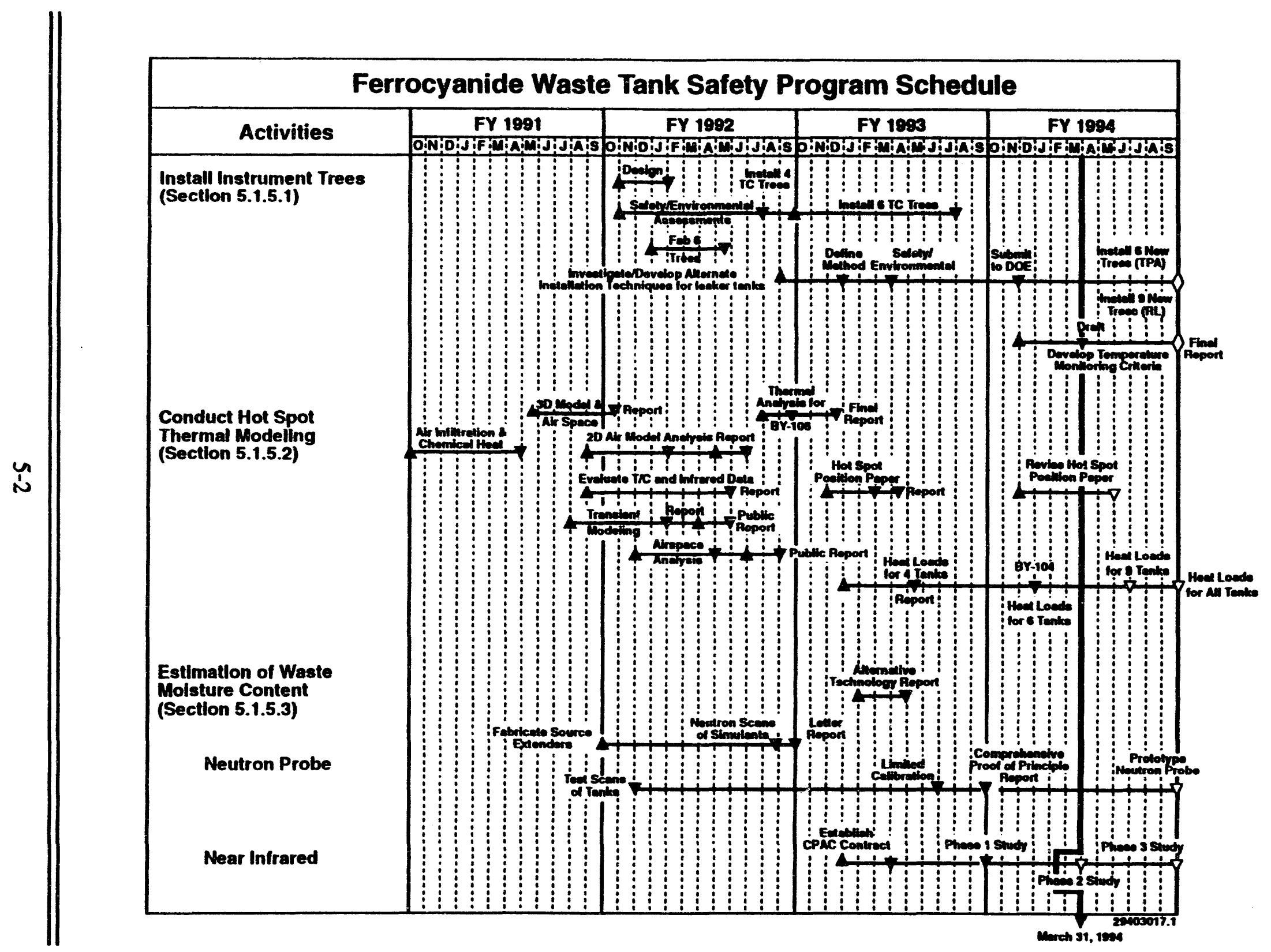


Figure 5-1. Ferrocyanide Waste Tank Safety Schedule. (Sheet 2 of 4)

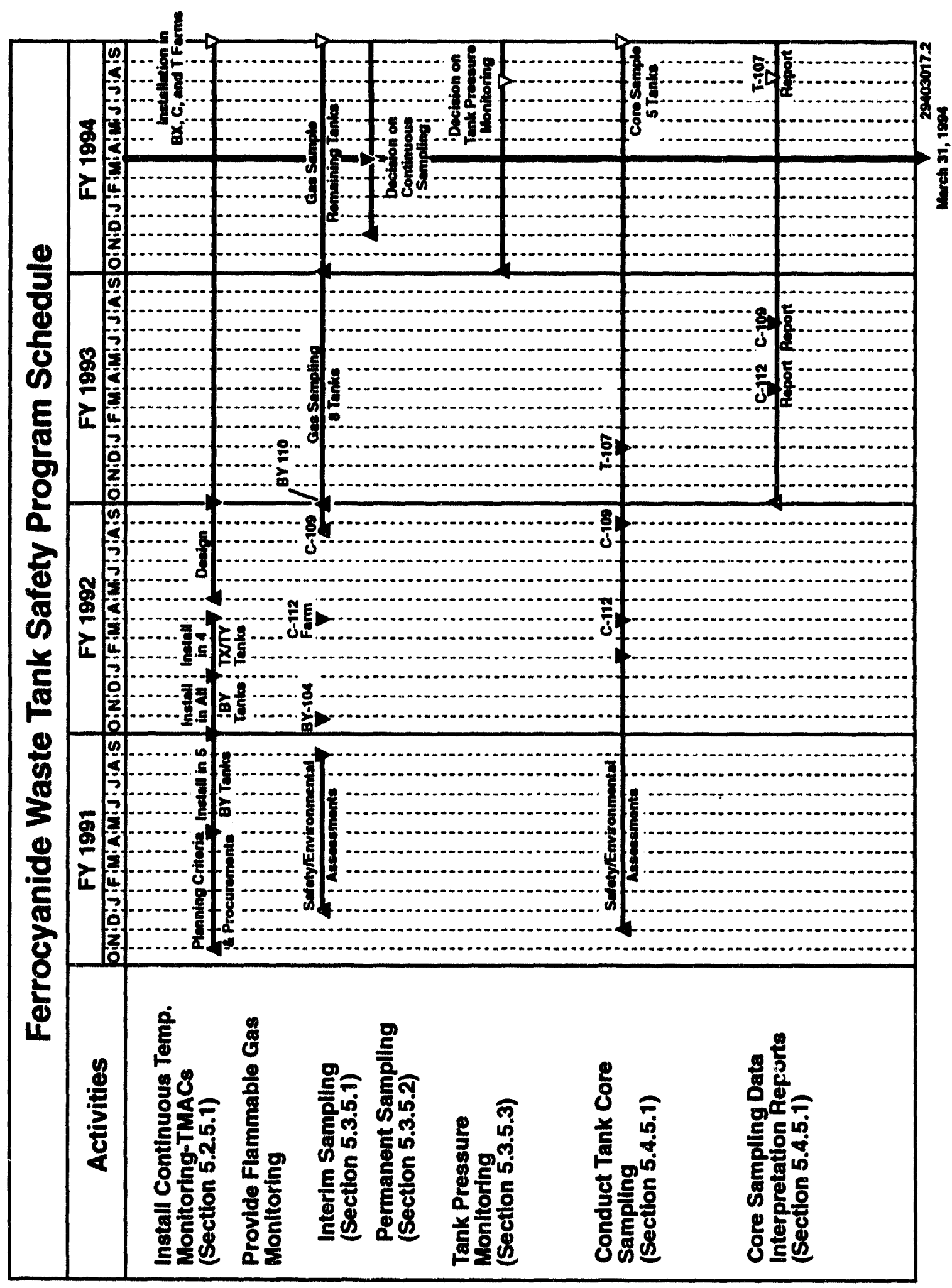




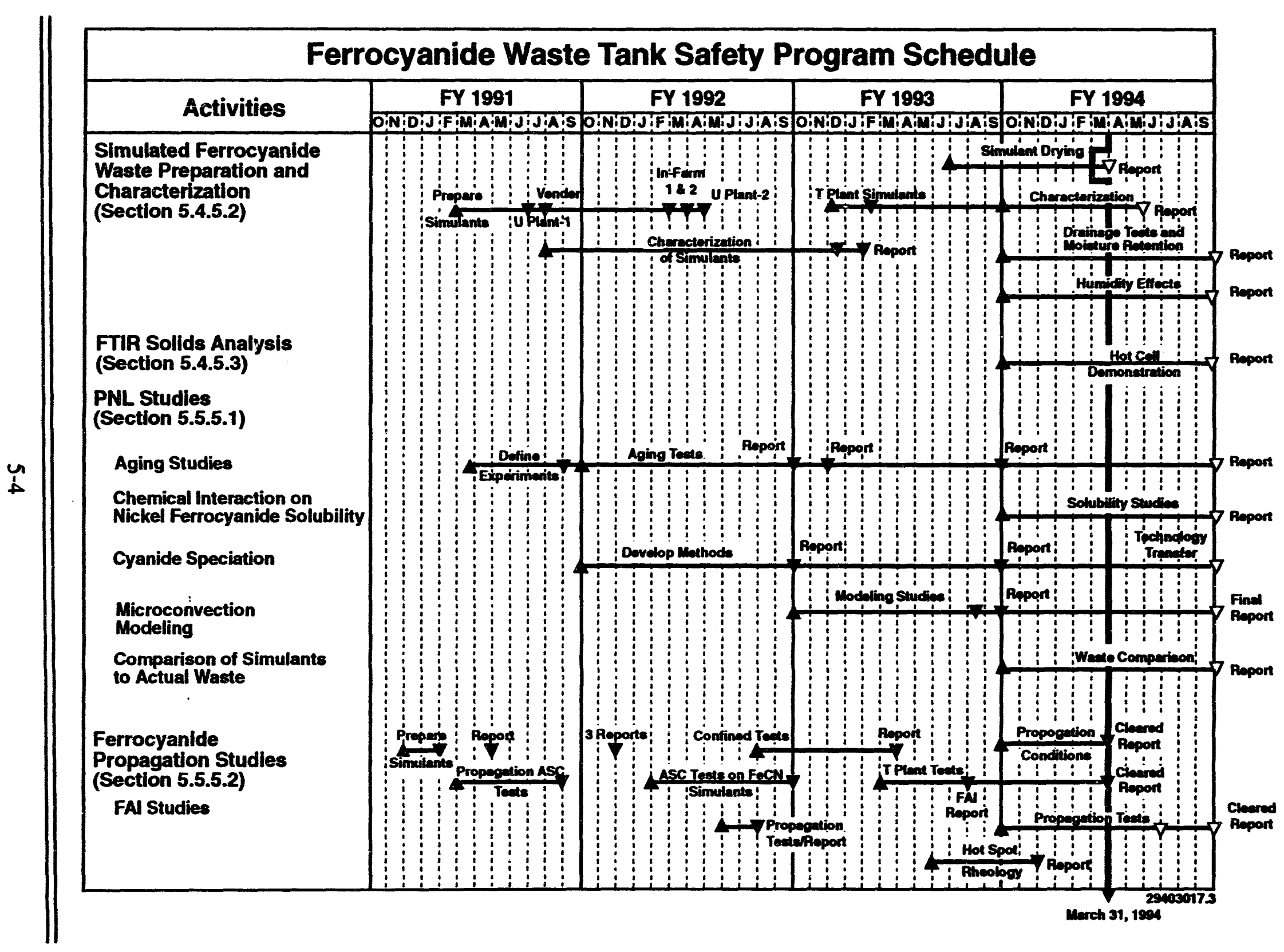

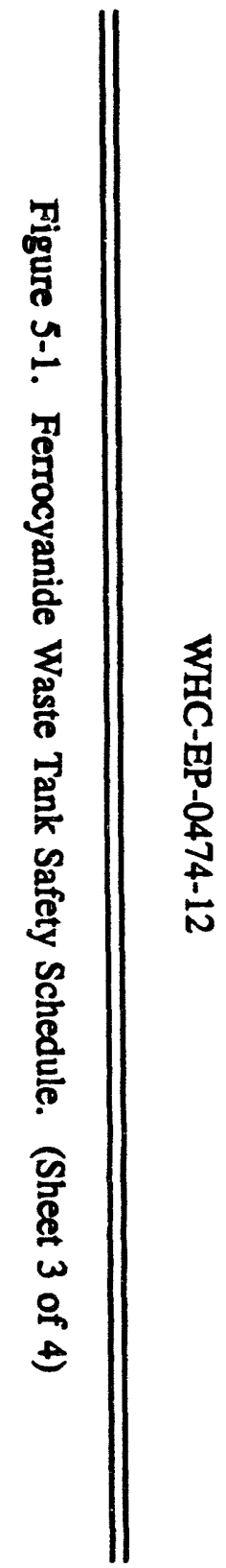




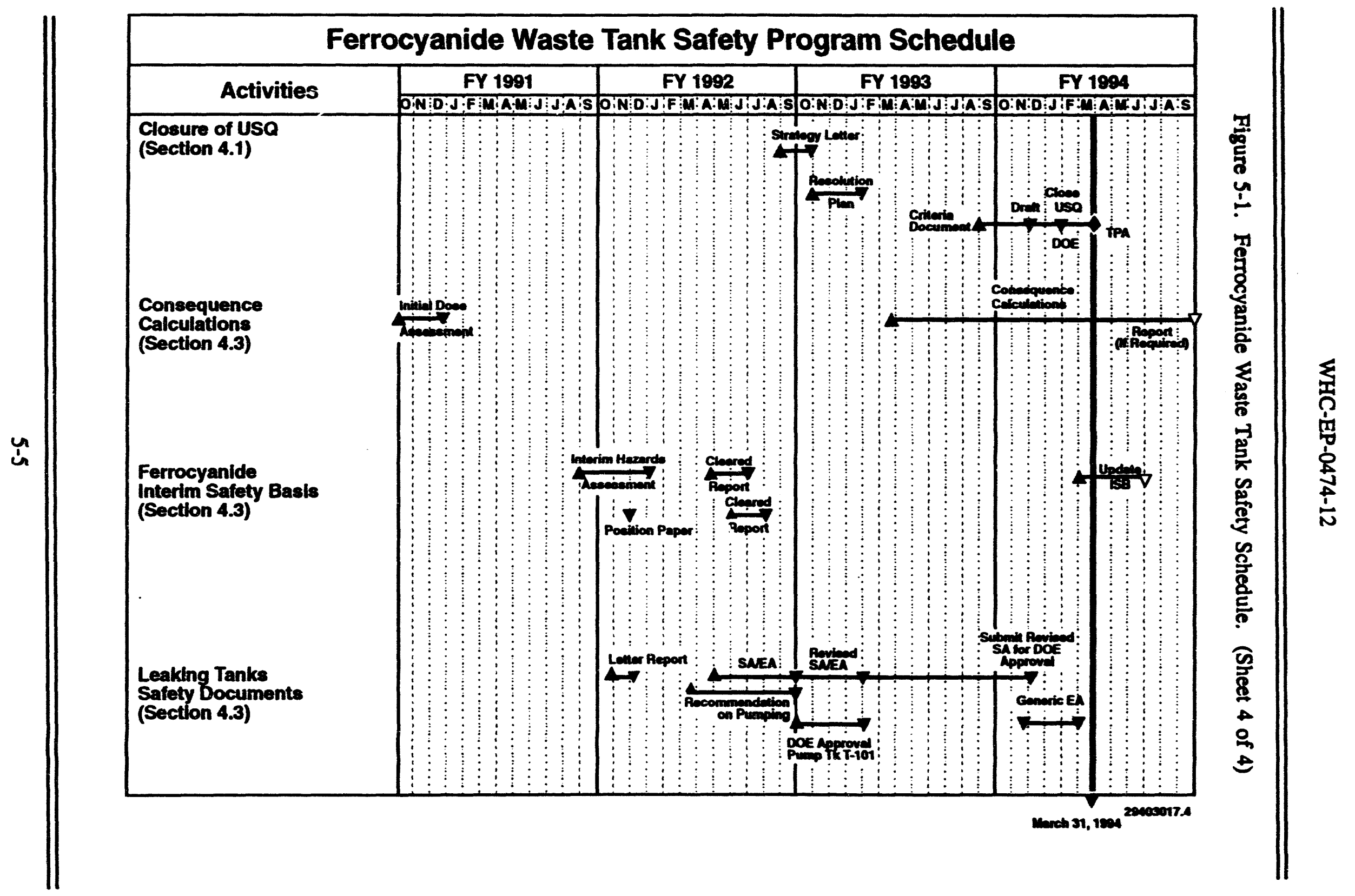


Figure 5-2. Ferrocyanide Waste Tank Safety Schedule (Out Year). (Sheet 1 of 2)

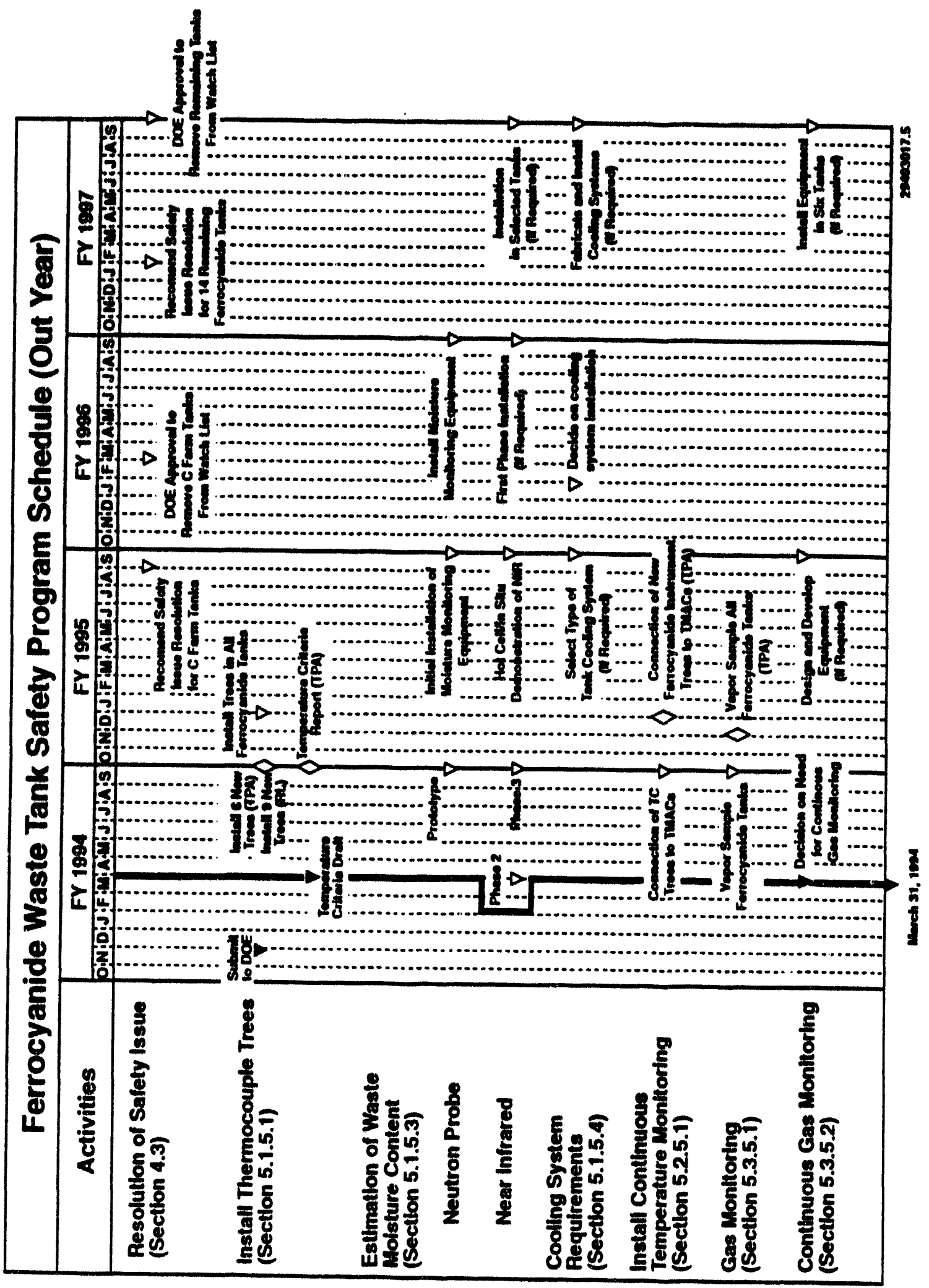




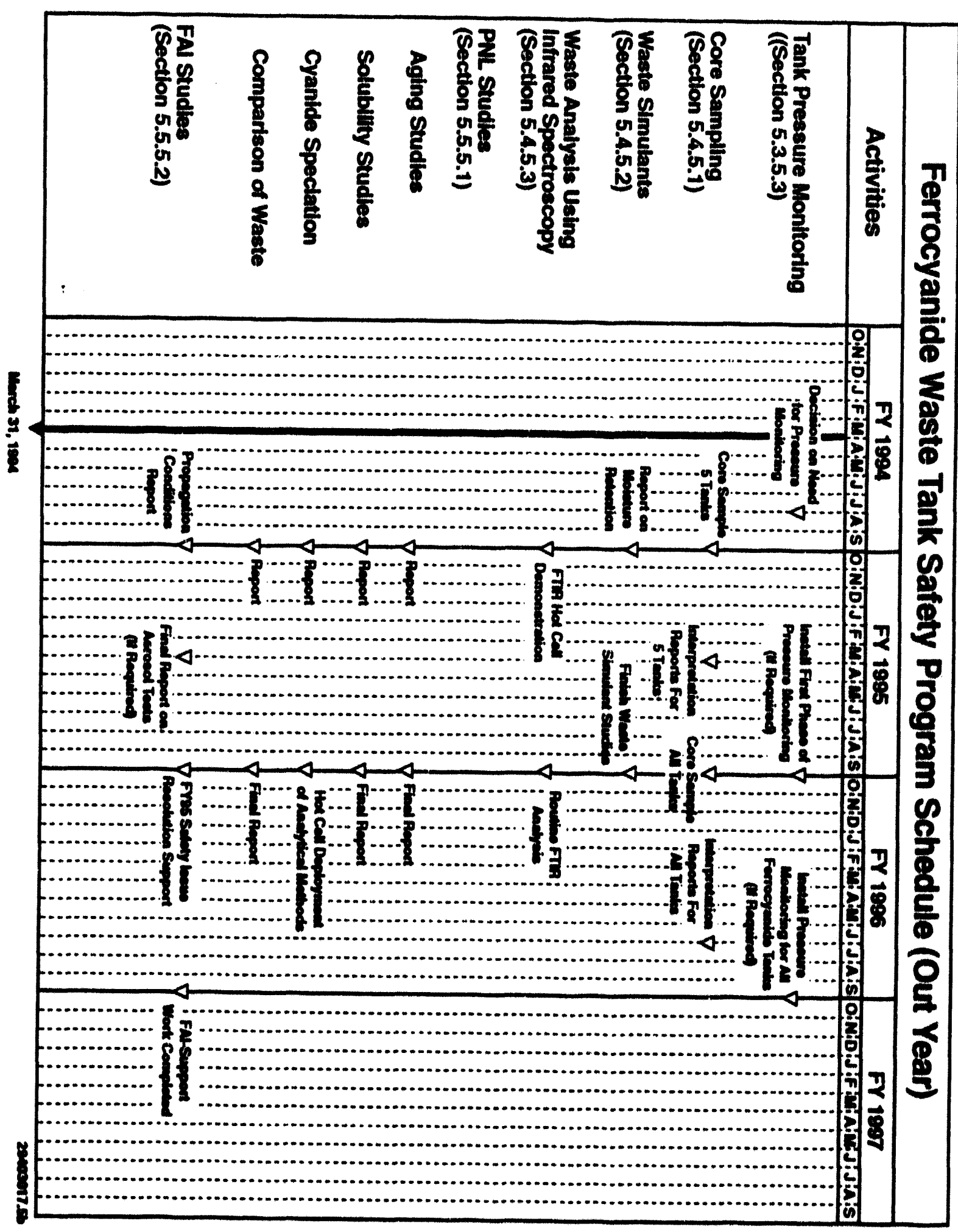

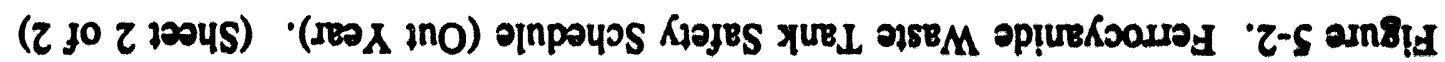


This page intentionally left blank. 


\subsection{REFERENCES}

Alumbal, W. T., 1994, Ferrocyanide Safery Program: Request for Closure of the Ferrocyanide Unreviewed Safery Question, (external letter 9450271 to J. H. Anttonen, U.S. Department of Energy-Richland Operations Office, January 13, 1994), Westinghouse Hanford Company, Richland, Washington.

Borsheim, G. L., and B. C. Simpson, 1991, An Assessment of the Inventories of Ferrocyanide Watch List Tanks, WHC-SD-WM-EP-133, Rev. 0, Westinghouse Hanford Company, Richland, Washington.

Borshein, G. L., R. J. Cash, and G. T. Dukelow, 1992, Implementation Plan for the Dipense Nuclear Facilities Safety Board Recommendation 90-7, WHC-EP-0415, Ruv. 1, Westinghouse Hanford Company, Richland, Washington.

Borsheim, G. L., J. E. Meacham, R. J. Cash, and B. C. Simpson, 1993, Ferrocyanide Safety Program: Rationale for Removing Six Tanks From the Safery Wasch List, WHC-MR-0429, Westinghouse Hanford Company, Richland, Washington.

Borsheim, G. L., J. E. Meacham, R. J. Cash, and G. T. Dukelow, 1994, Program Plan for Evaluation of the Ferrocyanide Waste Tank Safery Issue at the Hanford Site, WHC-EP-0721, Westinghouse Hanford Company, Richland, Washington.

Buck, J. W., C. M. Anderson, B. A. Pulsipher, P. J. Turner, J. J. Toth, R.J. Cash, G. T. Dukelow, and J. E. Meacham, 1993, Ferrocyanide Safety Program: Data Requirements for the Ferrocyanide Safety Issue Developed Through the Data Quality Objectives (DQO) Process, WHC-EP-0728, Westinghouse Hanford Company, Richland, Washington.

Burger, L. L., and R. D. Scheele, 1988, Interim Report, Cyanide Safety Studies, PNL-7175, Pacific Northwest Laboratory, Richland, Washington.

Burger, L. L., 1989, Complexant Stability Investigation, Task 1 - Ferrocyanide Solids, PNL-5441, Pacific Northwest Laboratory, Richland, Washington.

Bussell, J. H., 1992, Engineering Evaluation of Thermocouples in Ferrocyanide Watch List Tanks, WHC-SD-WM-ER-134, Rev. 0 and Rev. 0A, Westinghouse Hanford Company, Richland, Washington.

Cash, R. J., 1991, Implementation Plan for the Defense Nuclear Facilities Safety Board Recommendation 90-7, WHC-EP-0415, Rev. 0, Westinghouse Hanford Company, Richland, Washington. 
Cash, R. J., and J. Thurman, 1991a, Action Plan for Response to Abnomal Conditions in Harfond Site Radioactive Waste Tanks Containing Ferrocyanide, WHC-EP-0407, Rev. 0, Westinghouse Hanford Company, Richland, Washington.

Cash, R. J., and J. Thurman, 1991b, Action Plan for Response to Abnormal Conditions in Hanford Ste Radioactive Waste Tanks Containing Ferrocyanide, WHC-EP-0407, Rev. 1, Westinghouse Hanford Company, Richland, Washington.

Cash, R. J., and G. T. Dukelow, 1992, Fiscal Year 1992 Program Plan for Evaluation of Ferrocyanide in the Hanford Site Waste Tanks, WHC-EP-0399, Rev. 2, Westinghouse Hanford Company, Richland, Washington.

Crowe, R. D., M. Kummerer, and A. K. Postma, 1993, Estimation of Heat Load in Waste Tanks Using Average Vapor Space Temperarures, WHC-EP-0709, Westinghouse Hanford Company, Richland, Washington.

Deaton, D. E., 1990, Unusual Occurrence - Unreviewed Safery Questions Regarding Tanks Containing Ferrocyanide, WHC-90-B003-R1 (Update 10-22-90), Westinghouse Hanford Company, Richland, Washington.

Dickinson, D. R., J. M. McLaren, G. L. Borsheim, and M. D. Crippen, 1993, Ferrocyanide Safety Program: Credibility of Drying Out Ferrocyanide Tank Waste by Hot Spots, WHC-EP-0648, Rev. 0, Westinghouse Hanford Company, Richland, Washington.

DOE, 1986, Safery of Nuclear Facilities, DOE Order 5480.5, U.S. Department of Energy, Washington, D.C.

DOE, 1987, Final Environmental Impact Statement, Disposal of Hanford Defense High-Level, Transuranic and Tank Waste, Hanford Site, Richland, Washington, DOE/EIS-0113, Vol. 1 through 5, U.S. Department of Energy, Washington, D.C.

DOE, 1991, Unreviewed Safery Questions, DOE Order 5480.21, U.S. Department of Energy, Washington, D.C.

DOE, 1994, Recommendation 93-5 Implementation Plan, DOE/RL 94-0001, U.S. Department of Energy, Richland Operations Office, Richland, Washington.

Epstein, M., H. K. Fauske, and J. E. Meacham, 1994, Conditions for Reaction Propagation in Dried Ferrocyanide/Nitrate-Nitrite Powders, WHC-SD-WM-TI-619, Rev. 0, Westinghouse Hanford Company, Richland, Washington. 
Fauske, H. K., and D. W. Jeppson, 1994, Adiabatic Calorimetry (RSST and VSP) Tests with Synthettc T Plant Flow Sheet Material, WHC-SD-WM-TI-621, Rev. 0, Westinghouse Hanford Company, Richland, Washington.

FR, 1990, "Implementation Plan for Recommendation 90-3 at the Department of Energy's Hanford Site, Washington," Federal Register, Defense Nuclear Facilities Safety Board Recommendation 90-7, Vol. 55, No. 202, pp. 42243 - 42244.

Grumbly, T. P., 1993, Strategy for [Ferrocyanide] Safety Issue Resolution, (letter to J. T. Conway, Chairman, Defense Nuclear Facilities Safety Board, August 25, 1993), U.S. Department of Energy, Washington, D.C.

Meacham, J. E., R. J. Cash, and G. T. Dukelow, 1993, Quarterly Report on Defense Nuclear Facilities Safety Board Recommendation 90-7 for the Period Ending September 30, 1993, WHC-EP-0474-10, Westinghouse Hanford Company, Richland, Washington.

Peach, J. D., 1990, Consequences of Explosion of Hanford's Single-Shell Tanks are Understated, (letter B-241479 to M. Synar, Chairman, Environment, Energy, and Natural Resources Subcommittee, Committee on Government Operations, House of Representatives, October 10, 1990), GAO/RCED-91-34, U.S. General Accounting Office, Washington, D.C.

Postma, A. K., J. E. Meacham, G. S. Barney, G. L. Borsheim, R. J. Cash, M. D. Crippen, D. R. Dickinson, J. M. Grigsby, D. W. Jeppson, M. Kummerer, J. M. McLaren, C. S. Simmons, and B. C. Simpson, 1994, Ferrocyanide Safety Program: Safery Criteria for Ferrocyanide Watch List Tanks, WHC-EP-0691, Westinghouse Hanford Company, Richland, Washington.

Public Law 101-510, Section 3137, 1990, Safety Measures for Waste Tanks at Hanford Nuclear Reseryation, U.S. Congress, Washington, D.C. [Also referred to as the Wyden Amendment]

Rebagay, T. V., D. A. Dodd, D. W. Jeppson, 1993, Measurement of Ferrocyanides and Oxyanions in Waste Sludges by Fourier Transform Infrared Reflection Methods, * WHC-SA-1482-FP, Westinghouse Hanford Company, Richland, Washington.

Rebagay, T. V., D. A. Dodd, D. W. Jeppson, L. L. Lockrem, and G. R. Blewett, 1994, In Situ Chemical Characterization of Waste Sludges Using FTIR-Based Fiber Optic Sensors, WHC-SA-1987-FP, Westinghouse Hanford Company, Richland, Washington.

RHO, 1986, Single-Shell Tank Isolation Safety Analysis Report, SD-WM-SAR-006, Rev. 2, Rockwell Hanford Operations, Richland, Washington. 
Sheridan, T. R., 1994, Closure of the Ferrocyanide Unreviewed Safety Question, (external letter 94-SST-052 to A. L. Trego, Westinghouse Hanford Company, March 4, 1994), U.S. Department of Energy-Richland Operations Office, Richland, Washington.

Simpson, B. C., G. L. Borsheim, and L. Jensen, 1993a, Tank Characterization Report: Tank 241-C-109, WHC-EP-0688, Westinghouse Hanford Company, Richland, Washington.

Simpson, B. C., G. L. Borsheim, and L. Jensen, 1993b, Tank Characterization Data Report: Tank 241-C-112, WHC-EP-0640, Rev. 1, Westinghouse Hanford Company, Richland, Washington.

Wagoner, J. D., 1993, Approval of Hanford Site Tank Farm Facilities Interim Safety Basis, (letter ADT:TOB 93-TOB-209 to T. M. Anderson, Westinghouse Hanford Company, November 18, 1993), U. S. Department of Energy-Richland Operations Office, Richland, Washington.

Watson, W. T., 1993, Proof of Principle Report for In-Tank Moisture Monitoring Using an Active Neutron Probe, WHC-EP-0695, Westinghouse Hanford Company, Richland, Washington.

WHC, 1991, Tank Farm Stabilization Plan for Emergency Response, WHC-SD-PRP-TI-001, Rev. 0, Westinghouse Hanford Company, Richland, Washington.

WHC, 1992, Management Requirements and Procedures, "Identification and Resolution of Unreviewed Safety Questions," WHC-CM-1-3, Section 5.12, Westinghouse Hanford Company, Richland, Washington.

Wisness, S. H., 1994, Completion of Hanford Federal Facility Agreement and Consent Order Interim Milestone M-40-14: Close Ferrocyanide Unreviewed Safety Question, (extemal letter 94-SST-085 to D. R. Sherwood, U.S. Environmental Protection Agency, and J. Stohr, Washington State Department of Ecology, March 30, 1994), U.S. Department of Energy-Richland Operations Office, Richland, Washington.

Wood, S. A., 1993, Gas Space Anàlysis For Tank C-109, WHC-SD-WM-ER-183, Rev. 0, Westinghouse Hanford Company, Richland, Washington. 
WHC-EP-0474-12

APPENDIX A

FERROCYANIDE TANKS

A-1 
WHC-EP-0474-12

This page intentionally left blank. 
Table A-1. Summary of Contents and Status of Ferrocyanide Tanks'.

\begin{tabular}{|c|c|c|c|c|c|}
\hline Tank & $\begin{array}{c}\text { Total waste } \\
\text { volume } \\
(1,000 \mathrm{gal})\end{array}$ & $\begin{array}{c}\mathrm{FeCN} \\
\left(1,000 \mathrm{~g} \mathrm{~mol}^{\mathrm{b}}\right)\end{array}$ & $\begin{array}{l}\text { Heat load } \\
(\mathrm{Btu} / \mathrm{h})^{\mathrm{c}}\end{array}$ & $\begin{array}{l}\text { Maximum } \\
\text { temp. } \\
\left({ }^{\circ} \mathrm{C}\right)\left({ }^{\circ} \mathrm{F}\right)\end{array}$ & Status of tanks \\
\hline BX-102 & 96 & $<1$ & 2,800 & $18 \quad 64$ & IS; AL \\
\hline BX-106 & 46 & $<1$ & 2,500 & $\begin{array}{ll}18 & 64 \\
17^{\circ} & 62\end{array}$ & NS; Sound \\
\hline BY-103 & 400 & 66 & 5,500 & $\begin{array}{ll}27 & 81\end{array}$ & NS; AL \\
\hline BY-104 & 406 & 83 & 8,700 & $\begin{array}{ll}52 & 126 \\
46^{\circ} & 114\end{array}$ & IS; Sound \\
\hline BY-105 & 503 & 36 & 8,700 & $\begin{array}{ll}45 & 113 \\
49 & 120\end{array}$ & NS; AL \\
\hline BY -106 & 642 & 70 & 10,100 & $53 \quad 128$ & NS; AL \\
\hline BY-107 & 266 & 42 & 8,900 & $34 \quad 94$ & IS; AL \\
\hline BY-108 & 228 & 58 & 9,200 & $\begin{array}{ll}43 \quad 109 \\
\end{array}$ & IS; AL \\
\hline BY-110 & 398 & 71 & 6,900 & $\begin{array}{ll}47 & 117 \\
42^{e} & 108\end{array}$ & IS; Sound \\
\hline BY-111 & 459 & 6 & 5,500 & $\begin{array}{ll}31^{f} & 87 \\
29^{e} & 84\end{array}$ & IS; Sound \\
\hline BY-112 & 291 & 2 & 6,100 & $\begin{array}{ll}28^{f} & 82 \\
31^{\mathrm{e}} & 88\end{array}$ & IS; Sound \\
\hline C-108 & 66 & 25 & 6,000 & $\begin{array}{ll}21 & 69 \\
25^{\mathrm{e}} & 77\end{array}$ & IS; Sound \\
\hline$C-109$ & 66 & 6.88 & 7,000 & $\begin{array}{ll}24 & 76 \\
24^{\circ} & 76\end{array}$ & IS; Sound \\
\hline C-111 & 57 & 33 & 6,400 & 22 & IS; AL \\
\hline C-112 & 104 & $11.5^{8}$ & 7,500 & $\begin{array}{ll}26 & 79 \\
25^{\circ} & 77\end{array}$ & IS; Sound \\
\hline$T-107$ & 180 & 5 & 3,000 & $\begin{array}{ll}19 & 67\end{array}$ & NS; AL \\
\hline TX-118 & 347 & $<3$ & 4,600 & $\begin{array}{cc}24 & 76 \\
-- & --\end{array}$ & IS; Sound \\
\hline
\end{tabular}


Table A-1. Summary of Contents and Status of Ferrocyanide Tanks".

\begin{tabular}{|c|c|c|c|c|c|}
\hline Tank & $\begin{array}{c}\text { Total waste } \\
\text { volume } \\
(1,000 \mathrm{gal})\end{array}$ & $\begin{array}{c}\mathrm{FeCN}^{\mathrm{b}} \\
\left(1,000 \mathrm{~g} \mathrm{~mol}^{2}\right)\end{array}$ & $\begin{array}{l}\text { Heat load } \\
(\text { Btu/h) }\end{array}$ & $\begin{array}{l}\text { Maximum } \\
\text { temp. } \\
\left({ }^{\circ} \mathrm{C}\right)\left({ }^{\circ} \mathrm{F}\right)\end{array}$ & Status of $\tan k s^{d}$ \\
\hline TY-101 & 118 & 23 & 3,100 & 64 & IS; AL \\
\hline TY-103 & 162 & 28 & 4,000 & 19 & IS; AL \\
\hline TY-104 & 46 & 12 & 3,000 & 18 & IS; AL \\
\hline
\end{tabular}

- Reflects removal of four ferrocyanide tanks from Watch List in July 1993. Tank information and temperature data as of March 1994.

- Inventories from Borsheim and Simpson (1991).

- Heat load values from Table 7-1 in Crowe et al. (1993).

d IS - Interim Stabilized Tank; NS - Not Stabilized; AL - Assumed Leaker Tank; Sound - Non-Leaking Tank.

- Readings from new instrument trees; tank 241-BY-105 already had two trees.

f Reading from TC element in LOW.

- Calculated as ferrocyanide $\left[\mathrm{Fe}(\mathrm{CN})_{6}^{4}\right]$ based on the total cyanide values reported in Simpson et al. (1993a, 1993b).

- Readings have not yet been taken on this new instrument tree. 
Table A-2. Ferrocyanide Tank Vapor Sampling Summary

\begin{tabular}{|c|c|c|c|c|c|c|c|}
\hline Tank ${ }^{1}$ & $\begin{array}{c}\text { Date } \\
\text { Sampled }\end{array}$ & $\begin{array}{c}\text { Flamm } \\
(\% \text { LFL })\end{array}$ & $\begin{array}{c}\text { Org. Vapor } \\
(\mathrm{ppm})\end{array}$ & $\begin{array}{c}\text { Ammonia } \\
(\mathrm{ppm})\end{array}$ & $\begin{array}{c}\text { HCN/CN } \\
(\mathrm{ppm})\end{array}$ & $\begin{array}{c}\text { Hydrazine } \\
(\mathrm{ppm})\end{array}$ & $\begin{array}{c}\text { Nitrous Gas } \\
(\mathrm{ppm})\end{array}$ \\
\hline BY-104 & $\begin{array}{l}10 / 16 / 91- \\
10 / 30 / 91\end{array}$ & 1.0 & 37.2 & 250 & $<2$ & $>3.0^{2}$ & $>10$ \\
\hline C-112 & $\begin{array}{l}03 / 09 / 92- \\
03 / 18 / 92\end{array}$ & $<1.0$ & $<0.2$ & $<5$ & $<2$ & $<0.2$ & $<2$ \\
\hline C-109 & $08 / 26 / 92$ & $<1.0$ & - & $<5$ & $<2$ & $<0.2$ & $<0.5$ \\
\hline BY-110 & $09 / 27 / 92$ & $<1.0$ & 350 & $612^{3}$ & $<2$ & $<0.2$ & $<0.5$ \\
\hline T-107 & $10 / 22 / 92$ & $<1.0$ & 24 & 203 & $<2$ & $<0.2$ & $<0.5$ \\
\hline BY-111 & $03 / 25 / 93$ & $<1.0$ & 6.3 & 10.2 & $<2$ & $<0.2$ & $<0.5$ \\
\hline BY-112 & $03 / 26 / 93$ & $<1.0$ & 5.9 & 10.0 & $<2$ & $<0.2$ & $<0.5$ \\
\hline BX-106 & $06 / 17 / 93$ & $<1.0$ & 12 & 17.9 & $<2$ & $<0.2$ & $<0.5$ \\
\hline C-108 & $07 / 23 / 93$ & $<1.0$ & 1.2 & $<2$ & $<2$ & $<0.2$ & $<0.5$ \\
\hline TX-118 & $07 / 28 / 93$ & $<1.0$ & 0.3 & 10.1 & $<2$ & $<0.2$ & 0.5 \\
\hline C-111 & $08 / 11 / 93$ & $<1.0$ & $<0.2$ & $<2$ & $<2$ & $<0.2$ & $<0.5$ \\
\hline
\end{tabular}

${ }^{1}$ Maximum reported values for sampling effort.

${ }^{2}$ High reading caused by ammonia interference.

${ }^{3}$ Approximation because concentration exceeded Dräger ${ }^{\mathrm{TM}}$ tube calibration range. 
WHC-EP-0474-12

This page intentionally left blank. 
WHC-EP-0474-12

APPENDIX B

METRIC CONVERSION CHART 
z-g

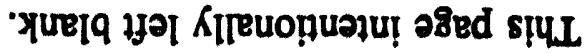

$2[-\nabla<+0-d]-D H M$ 


\begin{tabular}{|c|c|c|c|c|c|}
\hline 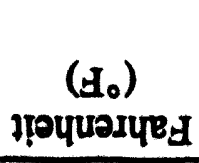 & 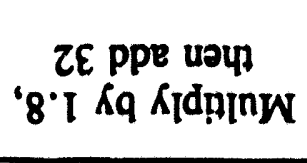 & (つ.) sn!spo & $\begin{array}{c}\text { (0.) } \\
\text { sn!̣səo }\end{array}$ & 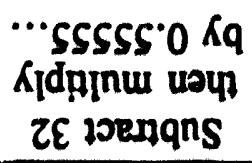 & 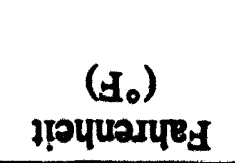 \\
\hline \multicolumn{3}{|c|}{ osniesoduoI } & \multicolumn{3}{|c|}{ arnjeredura L } \\
\hline [e8 & ZLIt9Z'0 & $\mathrm{I}$ & $\mathbf{T}$ & $\operatorname{It} S 8 L^{\circ} \varepsilon$ & [E8 \\
\hline \multicolumn{3}{|c|}{ ounjo $\Lambda$} & \multicolumn{3}{|c|}{ ounjo $\Lambda$} \\
\hline 9I & $\tau \cdot \tau$ & $8 x$ & $8 x$ & SISESt'0 & १І \\
\hline \multicolumn{3}{|c|}{ (24810M) sseN } & \multicolumn{3}{|c|}{ (248ి!̣M) sรEบ } \\
\hline 'u! & $\nabla 0$ & wo & wo & $87^{\circ} 0 \varepsilon$ & y \\
\hline 'थ! & +0.0 & ww & wo & $t s \cdot \tau$ & 'u! \\
\hline \multicolumn{3}{|c|}{ 478บบร } & \multicolumn{3}{|c|}{ บ18นขอ } \\
\hline 100 OL & Kg KIdp̣inu & Moury noX II & 190 OL & 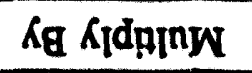 & Moux noX II \\
\hline \multicolumn{3}{|c|}{ DH⿻上丨 jo ino } & \multicolumn{3}{|c|}{ 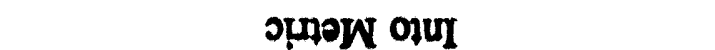 } \\
\hline
\end{tabular}

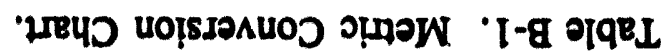


WHC-EP-0474-12

This page intentionally left blank. 


\section{DISTRIBUTION}

Number of copies

\section{OFESTTE}

6

U.S. Department of Energy

EM-36, Trevion II

12800 Middlebrook Road

Germantown, MD 20874

James V. Antizzo

Charles O'Dell (5)

1

U.S. Department of Energy

Savannah River Operations Office

P.O. Box A

Aiken, SC 29808

Thomas C. Temple

1

Charles S. Abrams

1987 Virginia

Idaho Falls, ID 83404

1

David O. Campbell

102 Windham Road

Oak Ridge, TN 37830

1

Fred N. Carlson

6965 North 5th West

Idaho Falls, ID 83401

1 Billy C. Hudson

2472 Marbury Road

Livermore, CA 94550

1

Arlin K. Postma

3640 Ballard Road

Dallis, OR 97338

1

William R. Prindle

1556 Crestline Drive

Santa Barbara, CA 93105 


\section{DISTRIBUTION (cont)}

\section{Number of copies}

\section{OPESITE}

Alfred Schneider

5005 Hidden Branches Drive

Dunwoody, GA 30338

1

Air Products \& Chemicals. Inc. 7201 Hamilton Blvd

Allentown, PA 18195-1501

George E. Schmauch

1

Battelle Columbus Laboratories

505 King Avenue

Columbus, OH 43201-2693

James A. Gieseke

1

Brookhaven National Laboratory

Upton, NY 11973

Kamal K. Bandyopadhyay

1

Desien Science, Inc.

163 Witherow Road

Sewickley, PA 15143

Gary Powers

1 Eauske and Associates, Inc.

16W070 W. 83rd St.

Burr Ridge, IL 60521

Hans K. Fauske

1

Elorida State University

Department of Chemistry B-164

Tallahassee, FL 32306

Greg R. Choppin 


\section{DISTRIBUTION (cont)}

Number of copies

\section{OEFSUTE}

1

Haryard University

295 Upland Avenue

Newton Highlands, MA 02161

Melvin W. First

1

4

1

1
Hazards Research Compration

200 Valley Road, Suite 301

Mt. Arlington, NJ 07856

Chester Grelecki

Los Alamos National Laboratory

P.O. Box 1663

Los Alamos, NM 87545

Steve F. Agnew

Steve W. Eisenhawer

Thomas E. Larson

L. Harold Sullivan

MTT/Department of Nuclear Engineering

77 Massachusetts Ave.

Room 24-102

Cambridge, MA 02139

Mujid S. Kazimi

Nuclear Consulting Services. Inc.

P.O. Box 29151

Columbus, OH 43229-0151

J. Louis Kovach 


\section{DISTRIBUTION (cont)}

\section{Number of copies}

\section{OFFSITE}

Oak Ridge National Laboratory

1

Emory D. Collins

P.O. Box 2008

7930, MS-6385

Oak Ridge, TN 37831-6385

1

Charles W. Forsberg

P.O. Box 2008

MS-6495

Oak Ridge, TN 37831-6495

1

Thomas S. Kress

P.O. Box 2009

9108, MS-8088

Oak Ridge, TN 37831-8088

1

Rice University

5211 Paisley

Houston, TX 77096

Andrew S. Veletsos

2

Sandia National Laboratories

P.O. Box 5800

Albuquerque, NM 87185

Dana A. Powers, MS-0744

Scott E. Slezak, MS-0741

3

Science Applications International Corporation

20300 Century Blvd, Suite 200-B

Germantown, MD 20874

Ray S. Daniels (3) 


\section{DISTRIBUTION (cont)}

Number of copies

\section{OFESITE}

2

1

1

1

1
State of Washington

Department of Ecology

P. O. Box 47600

Olympia, WA $98504-7600$

Michael T. Gordon

Megan E. Lerchen

University of South Carolina

Department of Electrical and Computer Engineering

Swearingen Engineering Center

Columbia, SC 29208

Joseph S. Byrd

University of Washington

Center for Process Analytical Chemistry

Chemistry Department BG-10

Seattle, WA 98195

Bruce R. Kowalski

Vanderbilt University

P.O. Box 1596, Station B

Nashville, TN 37235

Frank L. Parker

Waste Policy Institute

555 Quince Orchard Road, Suite 600

Gaitherburg, MD 20878-1437

Donald T. Oakley 


\section{DISTRIBUTION (cont)}

Number of copies

ONSITE

12

U.S. Department of Energy.

Richland Operations Office

R. F. Christensen (4) R3-72

R. E. Gerton (4) R3-72

A. G. Krasopoulos A4-81

Public Reading Room H2-53

RL Docket File (2) H5-36

$9 \quad$ Pacifi: Northwest Laboratory

S. A. Bryan $\quad$ P7-25

A. R. Felmy K6-82

B. M. Johnson K1-78

M. A. Lilga P8-38

B. P. McGrail K2-38

R. D. Scheele P7-25

G. F. Schiefelbein P8-38

D. M. Strachan K2-44

Hanford Technical Library $\quad$ P8-55

53 Westinghouse Hanford Company

$\begin{array}{ll}\text { H. Babad } & \mathbf{R 2}-78\end{array}$

G. A. Barnes H5-09

$\begin{array}{ll}\text { J. B. Billetdeaux } & \text { R2-08 }\end{array}$

D. C. Board $\quad$ S1-57

G. L. Borsheim $\quad$ R2-11

D. R. Bratzel R2-18

S. R. Moreno B3-06

$\begin{array}{ll}\text { R. J. Cash (2) } & \text { R2-78 }\end{array}$

M. D. Crippen L5-31

G. M. Christensen H4-21

D. R. Dickinson L5-31

G. T. Dukelow $\quad$ R2-78

S. J. Eberlein L5-55

J. M. Grigsby Hi4-62

$\begin{array}{ll}\text { J. M. Held } & \text { R3-09 }\end{array}$ 


\section{DISTRIBUTION (cont)}

Number of copies

ONSITE

Westinghouse Hanford Company (cont)

T. M. Hohl

S4-25

M. E. Huda

R3-08

M. N. Islam

R3-08

D. W. Jeppson

L5-31

C. V. King

S4-25

N. W. Kirch

R2-11

C. A. Kuhlman

B3-30

M. Kummerer

H4-62

J. D. McCormack

L5-31

J. M. McLaren

H0-34

J. E. Meacham (2)

R2-78

N. J. Milliken

H4-62

T. L. Moore, Sr

H5-09

A. F. Noonan

B1-40

D. M. Ogden

H0-34

M. A. Payne

R2-50

R. S. Popielarczyk

R1-30

R. W. Reed

R1-51

F. R. Reich

LS-63

M. J. Schliebe

S4-25

C. P. Schroeder

L7-06

B. C. Simpson

R2-12

H. Toffer

H0-38

W. T. Watson

H0-38

W. D. Winkelman

L5-55

D. D. Wodrich

R2-79

D. D. Wodrich

R2-85

W. F. Zuroff

S6-85

Central Files

L8-04

Document Processing and Distribution (2)

L8-15

EDMC

H6-08

Information Release Administration (3)

R1-05

TFIC

R1-20 
WHC-EP-0474-12

This page intentionally left blank.

Distr-8 

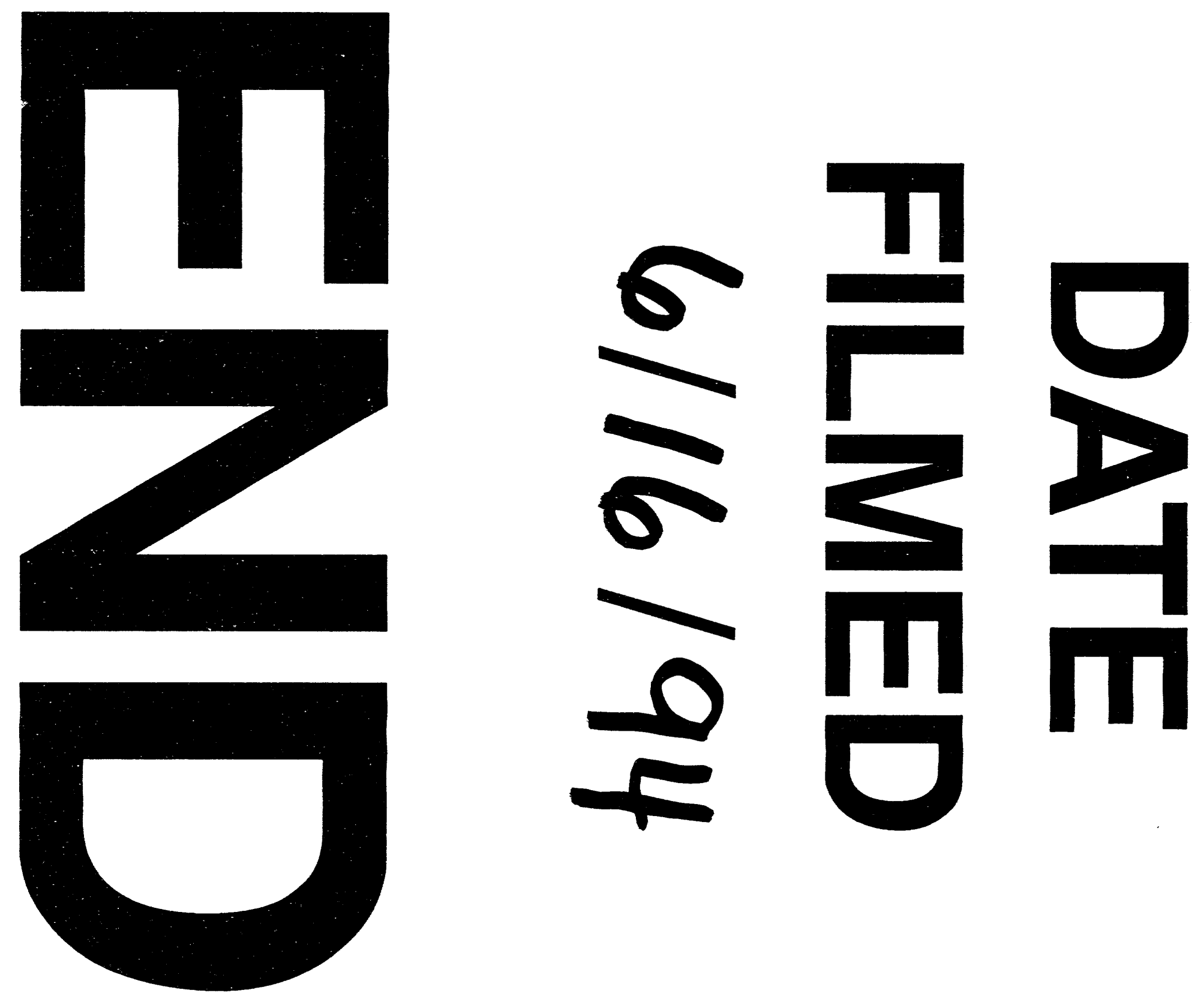
